\title{
CPEC: Threat or Opportunity Protecting Local Industry through Infant Industry Theory Framework
}

\author{
Manzoor Ali Isran ${ }^{1}$, Shehla Najib Siddiki ${ }^{1}$, Mukesh $\operatorname{Kumar}^{2}$ \& Erum Zahoor Zaidi ${ }^{1}$ \\ ${ }^{1}$ Department of Management Science, SZABIST, Karachi, Campus, Pakistan \\ ${ }^{2}$ IoBM, Karachi, Campus, Pakistan \\ Correspondence: Manzoor Ali Isran. E-mail: isran@szabist.edu.pk
}

Received: August 22, 2019 Accepted: September 5, $2019 \quad$ Online Published: September 29, 2019

doi:10.5539/ass.v15n10p104 URL: https://doi.org/10.5539/ass.v15n10p104

\begin{abstract}
China-Pakistan Economic Corridor is a massive investment initiative by China with a whopping amount of $\$ 62$ billion. The project includes various short term and long term plans for energy, infrastructure, IT and R\&D projects. The completion of short term plans by the end of 2018 and initiation of long term projects demand a comprehensive analysis as the project of CPEC presents both threat and opportunities for local producers. The threats include competition for local producers from innovative products of China and technological and managerial superiority of Chinese companies over Pakistani industry. However, the domestic producers feel more optimist as energy and infrastructure projects, and induction of new technology would benefit the business sector in Pakistan. The purpose of this study is to explore and identify the possible threats and opportunities considering "Infant Industry Theory" as an analytical framework. A qualitative and quantitative research methodology is employed and the data is gathered from 20 divergent and potential sector of SMEs through a close ended survey questionnaire. The likert scale is used to evaluate the opinions of respondents for awareness, challenges; and threats and opportunities of CPEC. The results revealed that SMEs owners are now more aware about the CPEC and its related details while the major challenges for producers were to cope with the low access to finance, unavailability of business and legal advisory services and difficulties in market access. Moreover, the majority of selected respondents consider the project of CPE as an opportunity for their businesses, industry and economy of Pakistan. It is thus concluded that business sector in Pakistan is preparing for CPEC, but with the fact that the required results are not possible till the challenges and concerns of local producers are addressed by the government in appropriate way through effective policies and efficient management. Hence, a detailed policy plan for the local industry specifying CPEC is highly recommended.
\end{abstract}

Keywords: CPEC, investment, trade, energy, infrastructure, security, political stability

\section{Introduction}

Pak-China relationship is taking new dimension and new directions keeping in view the changing realities in the regions. With China's rising economic power as a second largest economy in the world, it is looking for overseas markets. The One Belt One Road (OBOR) or Belt Road Initiative (BRI) is step in this direction in which China is investing more than $\$ 900$ billion, connecting 60 countries with $60 \mathrm{pc}$ of global population, 30c of global GDP and $35 \mathrm{pc}$ of global trade (Yu, 2018). China sees huge trade potential of OBOR regions and so far OBOR has done $\$ 5$ trillion trade. As for CPEC, it is a part of OBOR under which China is investing more than \$60billion. If we look at the structure and design of CPEC, it offers promises and perils: promises in the shape of opportunities to boost its dying economy and perils in the form of threat to the local business as they lack competitive power to compete against Chinese industry in the open market. Nonetheless, it is hoped that CPEC would produce win-win situation for both China and Pakistan and lead to the transformation in the economic outlook of Pakistan. Most of the Pakistanis believe that CPEC would open up new vistas of job creation, economic growth, and increase in exports through infrastructure development once the energy and other projects under CPEC are completed. Thus, the optimism is being shown that CPEC will lift all the boats from the surging waves of poverty, unemployment, illiteracy and death and disease Pakistanis are facing, especially in the underdeveloped province of Baluchistan, and distribute the investment evenly amongst all the provinces. To realize this goal, Pakistan needs what Lin Wang (2017) says that the improvement in the 'social governance' in order to distribute infrastructure, energy and technology and finally the gains of CPEC equally in the light of high hopes attached 
with project.

According to Yu (2018), a Chinese professor, "Pakistan's interests lie in promoting growth, private sector investment, employment, export, technology and transfer of skills as well as in the relocation of Chinese firms. China's interests lie in overseas production bases, new export markets, energy cooperation, and its need for production capacity relocation". And in this regard, she highlights two factors that favour Pakistan to benefit from huge Chinese investment. First, Pakistan is home to more than 200 million people and according to World Economic Forum it will be among the top five populous countries in the world by 2060. But Yu (2018) argues in the same breath that large population is not necessary condition to attract investment until it is not equipped with sufficient skills and knowledge to meet industrial requirements.

The Second factor that favours Pakistan is that Pakistan and China are hailed as all-weather friends, iron brother and as close as "lips and teeth. There is already strategic relationship that needs to be further deepened and turned into economic one. With CPEC," Pakistan will be able to propel itself into new era of development, improving road, air, and sea and energy infrastructure" (Ibid).

Apart from benefits CPEC will bring to Pakistan economy in the form of opportunities as stated above, there are sceptics who think that when CPEC is operational and SEZs are established, Pakistani Industry will not be able to compete against its Chinese counterparts. Further, Chinese industry is given preferential treatment in comparison to local industry and it is feared that it will be death knell for Pakistan's emerging industry.

The paper will do in-depth descriptive analysis of the impact of CPEC on the local industry using 'infant-industry theory'. Let us first understand what Infant Industry Theory is? According to online Dictionary Investopedia "the infant-industry theory is the supposition that emerging domestic industries need protection against international competition until they become mature and stable through the measures such as import duties, tariffs, quotas and exchange rate controls to prevent international competitors from matching or beating the prices of an infant industry, thereby giving the infant industry time to develop and stabilize". Online Business Dictionary defines infant industry as "new industry in its early stages of development, and in need of protection from predatory competition through tariff and non-tariff barriers until it is established". The paper will also survey the theoretical literature by finding out what are factors leading to FDI and what threats and opportunities FDI by digging deep into the properties of 'Benign and Malign Model'.

In the next session, paper is going to present the brief overview of the One Belt One Road (OBOR) in order to understand the local, regional and international dimension of the grand project that promises development for all.

\subsection{Brief Review of One Belt One Road}

Conceptualization and materialization of One Belt One Road is the extension of the Silk Road, established 2000 years ago. Silk Road was the network of trade routes that linked China to Central Asia and Arab World. In fact OBOR is an attempt to revive those trade routes and expand economic relationships with other countries.

CPEC started in 2013 when Chinese president Xi Jinping proposed its establishment. Most of the analysts believe that OBOR is the part of the imperialist design of china to expand its influence using the surplus money for infrastructure development in different countries. But Chines leadership denies it by saying that OBOR is purely for development (Ibid). But, if look at the structure and design of the OBOR, it has three dimension, namely, international, regional and local.

\subsubsection{International}

The OBOR concept has international strategic importance. The region OBOR covers has total population of 4.4 billion with total trade potential of $\$ 21$ trillion. OBOR consists of three routes, southern (Connects Kashgar with Pakistan at Kunjarab - a point from where China wants to link to Gwadar port in the Arabian Sea), central (from Shanghai and links China to Tashkent, Tehran and onwards to Bandar Imam Khomeini Port of Iran on the Persian Gulf. One of its branches goes up towards Europe) and northern route (from Beijing, passes through Russia, and links it to European cities).

\subsubsection{Regional}

The drive on the part of China to build economic roads, connecting China with different regional countries, is considered as the first organized attempt towards South-South cooperation as advocated by Dependency Theorist in 1960's as an alternative to capitalist development dominated by G-7 countries. With regard to CPEC, It is utmost attempt of the Chinese leadership to involve the regional countries, especially, India in the CPEC but India is willing for strategic reasons as some of the analysts see India and China as competing powers in the regions and US is consciously trying to boost India for that role. Still, the focus of CPEC is to enhance 
"improving economic growth, offering trade diversifications through regional cooperation and integration by investing in transportation, energy sector" (Ibid). Political and economic objectives are targeted to be achieved through trade and development via CPEC which will also strengthen the economic and trade cooperation amongst the regional countries and it is keen desire of China to get India in the CPEC as India happens to be one of the biggest market in South West Asia and if India gets on board, it will be big success of China not only in economic terms but strategic as well, as US has been attempting to woo India against the increasing economic and strategic influence of China in the India Ocean and South China Sea under Asia Pivot Policy, started by Obama Administration and being continued by Trump administration with addition of trade wars against China. Nevertheless, there is growing belief that after completion of the CPEC, it will function as a primary gateway for trade between China, Africa and Middle East, bringing more economic prosperity in the region (Ibid).

\subsubsection{Local}

CPEC has local dimension in terms of economic and technological connectivity of different regions of Pakistan namely, Baluchistan, Sindh, Punjab and Khyber Pakhtunkhwa. It is believed CPEC will bring so many windfalls. It will help out to overcome energy crisis as Pakistan grappling with to the extent it has been the cause of regime changes in Pakistan. It will lay down the infrastructure and help Pakistan to modernize its technology, develop human resources and improve management know-how. The benefits of CPEC won't be limited to Pakistan but China too will be reaping the same. As saying goes, the mutual interests bring countries together. Currently China ships almost $80 \mathrm{pc}$ oil from Strait of Malacca to Shanghai, costing it around \$18 million daily. The distance is almost about $16,000 \mathrm{~km}$, but with Gwadar it would be reduce to less than 5,000 km", bring the cost down to one third of the current levels (Ibid). According to experts, "Even if China were to use CPEC only for $50 \%$ of its current level of oil supplies, it will save around $\$ 6$ million every day, almost $\$ 2$ billion every year" (Salman, 2015). Further through CPEC, China will be able to integrate landlocked western parts with Gwadar and thereby develop them through industrialization and trade.

The project is expected to add 2 to 2.5percent to the annual economic growth to Pakistan economy (Ibid). Also, it is forecasted to add 2 million direct and indirect jobs to Pakistan's economy between 2015 and 2030. Of the total outlay of the project $\$ 34$ billion will be invested in energy projects, $\$ 16$ billion in infrastructure (roads and railways) projects, $\$ 793$ million in Gwadar Port and nearly $\$ 44$ million in other projects (Ibid).As these projects are located in four provinces of Pakistan, 16 in Baluchistan will have 16, KPK 8, 13 in Sindh and 12 in Punjab. Out of the total projects, 16 are currently in process of incipient development, all part of the early harvest plan which projects are stipulated to be completed between 2016-20209.

Three routes have been earmarked for CPEC, the western, central and eastern routes. The distribution of the corridor along three routes allows for access through all the four provinces. The Western route originating from Gwadar will pass through Turbat, Panjgur, Naag, Basima, Sohrab, Kalat, Quetta, QilaSaifullah, Zhob, DIK, Mianwali, Hasanabdal and Islamabad. Also, the central route will originate from Gwadar, Quetta and reach DI Khan via Basima, Khuzdar, Sukkar, Rajanpur, Liya, Muzaffargarh, Bhakkar. Lastly, the eastern route will include Gwadar, Basima, Khuzdar, Sukkur, Rahim Yar Khan, Bahawalpur, Lahore, Islamabad and Mansehra. This geographical spread of the corridor will provide economic benefits to all provinces with direct and indirect job creation possibilities.

\subsection{Implementation}

The implementation of CPEC projects has to be completed in four stages;

(i) Early Harvest 2015-2019 Most the energy related projects to be completed by 2019, adding 7000 megawatts to the national grid and helping reduce the load shedding and boosting industry and exports.

(ii) Short term projects to be completed up to 2022. They are mainly related to roads, the development of Gwadar, fiber optic network, hydel and coal mining and power projects.

(iii) Medium projects to be completed up to 2025. They are related to Railways and Industrial zones

(iv) Long term projects to be completed up to 2030 that contain the Completion of Industrial zones, Agriculture, Tourism, etc.

As said earlier, nations build relations on the basis of economic and strategic interests and every country has its own interests. Same is true of Pak-China relations. Both countries have deep strategic ties but their economic ties were not that much strong. As China has emerged as a rising economic power, it wants to give economic dimension to strategic ties in the region of South West Asia. Let us take brief snapshot of their relations in the next section. 


\subsection{Brief Review of China-Pak Relations}

Relations amongst nations are built on the basis of economic and strategic interests because we are living in very interdependent world where no nation can serve interests on its own without the assistance of others. The story of Pak-China friendship is a similar one; it is cemented by commonality of strategic and economic interests. China needs Pakistan to create counterweight to India and Pakistan needs China to counterbalance its relations with growing Indian hegemony in the region. So, the common Indian hostility has brought the two countries closer to each other. According to Professor Jing Dong, Associate Professor at Monterey Institute, shared hostility towards India has resulted in warm relations between China and Pakistan (Yuan, 2009). According to Hussain Haqqani, former ambassador of Pakistan to US, "For Pakistan, China is a high value guarantor of security against India" (Afridi \& Bajoria, 2010).

No doubt, the relations between Pakistan and China are exemplary and described more in poetic terms such as sweeter than honey, higher than Himalaya and deeper than Arabian Sea. Chinese leadership calls China and Pakistan as 'iron brothers', strategic and economic partners. This partnership, while standing on the iron rock has evolved over the period of more than sixty years. There have been ups and downs in regional and global situations, yet the ties between the two have been expanding and becoming deeper.

Pak-China relations are on the path of constant improvement and stability, and due to Chinese deeper interests to promote investment in the economic infrastructure, new options for Pakistan are opening up, as previously Pakistan was more dependent on the West for securing capital and technology which proved unhelpful. Critics say Western help comes with strings attached and it compromises the economic sovereignty of the country but on the other hand, Western and global financial institutions maintain that it is not the West but internal factors such as bad governance, corruption and wrong economic policies are responsible for the economic problems of Pakistan. As a result, no significant foreign investment is coming into the country due to political instability, poor infrastructure, lax laws and small capital market. Whatever loans are offered to Pakistan by international financial institutions such as IMF and World Bank are attached with conditionalities such as austerity measures and withdrawal of subsidies on food and essential utilities are causing pain to poor. Inflation is increasing and growth is plummeting; overall, macroeconomic indicators are very dismal. According to 2013 indicator cited by The World Bank, 60 percent of people are living below the poverty line.

The biggest question is: will Chinese assistance help Pakistan to overcome the current economic crisis? It will but it depends on what measures Pakistan takes with regards to internal stability, institutional innovation, transparency in decision making which seems to be absent from the menu of different governments of Pakistan. Now Pakistan has got new government of Imran Khan which seems to be keen to improve governance and create internal stability. And these efforts of Khan Government will be helpful for CPEC to improve Pakistan's economic conditions.

In the next section, paper is going to layout the importance of FDI in the development of local infrastructure and creation of jobs that ultimately propels host country into the new level of development provided FDI is managed well by setting the priorities and laying down the regulatory mechanism.

\section{FDI and Developing Country}

Foreign Direct Investment (FDI) is an important source of investment for the developing countries and recognized as a powerful engine of growth. It helps "capital-poor countries to build up physical capital, create employment opportunities, develop productive capacity, enhance skills of local labour through transfer of technology and managerial know-how, and help integrate the domestic economy with the global economy" (Fazlur, 2015). The proponents argue that through FDI capital-poor countries can bridge the gap between saving and investment, gets access to modern technology and management skill from industrialized countries. Moreover, it not only provides capital for investment but also helps in creating more employment opportunities. All these factors contribute to the economic growth of a country. FDI is also beneficial in reducing the saving-investment gap which is a common problem for many third-world countries including Pakistan (Zahid, 2013). Therefore, the inflow of foreign direct investment is very important for the economic growth of Pakistan and CPEC could be game changes provided it is managed well to contribute towards the productivity of our industrial sector.

Historically speaking, the countries suffering from the gap in the saving and investment, face technological and managerial deficiencies, look for overseas investment. China itself is glaring example of such development. In 1979, When Deng Xiaoping took over as the president of China, he opened China's economy to outside world. Heavy investment came in the form of capital and technology. Deng was criticized for this decision by hard core of communist party members on the ground that it could endanger communism and destabilize China. Deng responded criticism with his famous saying "it does not matter cat is black or white so long as it catches mice". 
Deng used the metaphor of cat for investment and managed investment very well. As a result, China has emerged as a strong powerhouse of manufacturing and its exports have increased exponentially. It is second largest economy in the world and being tipped to take over US by 2025 .

There are host of other examples of how countries developed due to overseas investment. Europe developed because of Marshall Plan in 1947 as it was ravaged by the WWII. Marshall Plan was one of the biggest overseas investments in Europe. US had twin interest - turn Europe into market for its MNC's and protect it from communist takeovers through development. South Korea, Singapore and Malaysia are also example of how overseas investment helped these countries in development of core human, technological and physical infrastructure that finally laid foundation of economic development.

CPEC, no doubt, is eco-strategic project through which China want to draw Pakistan into its economic model of development and help later to develop its infrastructure. However, to be a beneficiary of CPEC, federal government must ensure transparency in its decision making, improve management of the CPEC project, take provinces on the board and shed impression that CPEC is not solely for the development of Punjab but it is national project.

In the next section, paper is going to discuss the theoretical and conceptual framework in order to understand the very nature of FDI and discover the factors that attract it.

\section{Theoretical and Conceptual Frame Work}

There are no two opinions that FDI plays significant role in the development of host economy provided FDI are well-managed as it brings finance, technology and managerial skills in the host country due to which economic environment goes under tremendous change. As in the above section, paper has discussed the economic rise of China as a result of FDI in late seventies due to 'open door' policy of Deng Xiaoping that allowed foreign business to enter into the China and hence China's economic policy shifted to encourage and promote foreign trade and investment. In this section paper discusses the factors attracting investment and there are certain theories which largely clear the mist surrounding FDI. The study of theoretical literature shows location plays critical role in the decision of the firm to invest overseas. Firms always go for location-driven advantages such as locations abundant in natural resources, infrastructure, attractive business environment and availability of skilled labour. According to Popovici and Călin (2014) the choice of location is influenced by the behaviour or the motivation of the firm either in shape of resource seeking, market seeking or structure asset seeking. If we analyse the decision of the Chinese government to invest $\$ 62$ billion in the Pakistan, it becomes apparent that the decision looks more motivated by structure asset seeking than resource seeking or market seeking. There is majority view supporting the thesis that China's decision to invest in Pakistan is designed to get foothold in the Indian Oceans and access to Middle East as a part of its policy called 'pearl of strings' and Gwadar happens to be "jewel" in the pearl of string strategy. Further, with Gwadar and the road connecting Gwadar with Kashgar in Western China, China will have access to Middle Eastern Oil as discussed earlier. Further, the takeover of port Hambantota in Sri lanka by China is cited as glaring example of asset seeking after the failure of Sri lanka to pay off debts to China.

The literature also shows that institutional variables play role in attracting FDI. As any country having strong institutions with effective system of accountability and transparency plays significant role in attracting FDI. European countries and USA is glaring example where institutions are very strong and system of accountability and rule following very effective (Ibid). But in case of Pakistan, not only institutions are weak but have a weak system of accountability and transparency in decision making. Still large number of people have doubts about CPEC as government of Pakistan has not been able to make details of CPEC available to people. So here, we can say Institutional variable are not strong enough to get investment from China under CPEC but they are in case of USA, Europe, Japan, even China to some extent.

When we look at the earlier approaches, they suggest production and transportation were the main elements behind investment and trade. That is why trade and investment spread across the continents and laid the foundation for the colonization of resource-rich poor countries. In order to further deepen and understand the location advantages of investment, Dunning (1973) presented two theories namely Supply-Oriented and Demand-Oriented theory. According to Supply Theory, investment goes to the locations having low-cost production whereas Demand Theory purports that investment is done on the location of market and competitors. In this regard, the FDI is explained through four following location factors:

1. Existence of raw material (Baluchistan has abundant raw natural resources)

2. Cheap labour 
3. Unexploited and protected market

4. Transport Cost (KusLuran,1998)

In case of investment under CPEC, both theories sound viable because the areas where Special Economic Zones will be established has low cost labour and there is no sound competitor against Chinese firms and further due to strategic and economic considerations Chinese firms are given preferential treatment against their Pakistani competitors who have complained against such treatment at the hands of Pakistani government.

\subsection{The FSA-CSA Matrix}

- Rugman developed impressive conceptual framework in 1980, explaining further evolution of FDI. The matrix has two axes: on the first one are the firms specific advantages (FSA) consisting of the competitive advantages of the firm - technological development, the know-how level, marketing capacities and managerial abilities. The second axis is represented by the country specific advantages (CSA), consisting of the natural resources endowment, the quality of labour market, institutional characteristics or public policies dedicated to an attractive business environment (Rugman, 2007).

If we analyse CPEC in the light FSA-CSA Matrix we see FSA advantages are stronger than CSA, therefore, Chinese companies will have almost walkover in the marketing and the customization of the projects related to energy and infrastructure and establishment of SEZs.

Table 1. CFA and FSA Matrix of FDI in Pakistan

\begin{tabular}{|c|c|c|c|}
\hline & & Firm’s Specific Affects (FSA) & \\
\hline & & Weak & Strong \\
\hline \multirow{11}{*}{$\begin{array}{l}\text { Country } \\
\text { Specific } \\
\text { Affects } \\
\text { (CFAs) }\end{array}$} & \multirow{6}{*}{ Strong } & \multirow{6}{*}{$\begin{array}{c}\text { Agriculture base } \\
\text { Plentiful resources and land } \\
\text { Growing Infrastructure } \\
\text { Cheaper workforce } \\
\text { Receptive to financing services }\end{array}$} & R\&D \\
\hline & & & Wide Product offering \\
\hline & & & Understanding of domestic market \\
\hline & & & Good reputation \\
\hline & & & Strong support Services \\
\hline & & & Diverse Market \\
\hline & \multirow{5}{*}{ Weak } & Dependency on agriculture sector & \multirow{5}{*}{$\begin{array}{l}\text { Establishment of SEZs } \\
\text { Customization of the projects related } \\
\text { to energy and infrastructure }\end{array}$} \\
\hline & & Poor financial intermediary & \\
\hline & & Mediocre business environment & \\
\hline & & Insufficient investment in energy and infrastructure & \\
\hline & & Low access to international financial Markets & \\
\hline
\end{tabular}

\section{Impact of FDI on the Host Country}

FDI and its possible impact on the economy and development of host country is intensively debated in the community of researchers and academics and they have been trying to assess as to what impact FDI is having on the host economy? To find answers of the question, literature suggests that there are two alternative conceptualizations that provide guidance and understanding of its potential contribution to the host economy. The first one refers to the inputs investors bring in the host country in the form of technology, capital and managerial skills whereas the second refers to the potentially negative and distorting impact on the domestic economy due to imperfect nature of the local market.

Realistically speaking, both models are reasonably credible in terms of different outcomes. The one is positive and other is negative but we would like to say that the outcome of any FDI models is dependent on its management. Look at what outcomes China achieved when it allowed FDI to trickle in the china after 1978 when Deng Xiaoping took over the reins of China which under his leadership managed FDI very well despite cynicism shown by his critics. In case of CPEC, we would say it depends as to how Pakistan is managing it and how it provides support to its nascent industry which still is crawling and needs government crutches against Chinese companies which are more advanced in terms of technology, innovation and management. In the next section, paper is going to discuss the two approaches which are offshoot of above-cited two theoretical frameworks.

\subsection{Benign Model of FDI}

To further dig deep into the dynamics of FDI, let us have a look at Benign and Malign models that have been presented by Peterson Institute for Internal Economics think tank (2018). According to Benign Model, FDI is 
seen as panacea to break the vicious cycle of underdevelopment as the host country's economy is mired in poverty, low level of productivity, low wages which leads to low level of savings that perpetuates low level of investment and productivity. Amid that situation that host economy faces, FDI can break the ice by complementing local savings, along with support effective management, marketing and new cutting technologies.

\subsection{Malign Model of FDI}

There has been criticism of Benign Model and that criticism has mainly come from Marxist economists. They argue that MNCs exploit the natural resources and create pollution and deprive local populations of their sources of livelihood and finally it leads to disruption and devastation. According to them, MNCs in developing countries create pollution, don't follow health and safety regulations and don't pay minimum wage to workers set by the host country. They thwart local laws in connivance with local governments and bribe local politicians to extract more concessions. Pinochet regime in Chile, Sadam regime in Iraq and military junta in Myanmar are some of the glaring examples where FDI benefitted more outside companies than host country and local people.

Critics argue that mostly the companies operate in imperfect markets under FDI where there are no barriers to their entry, hence enjoying increasing market concentration. Critics maintain that instead of filling the gap between saving and investment, FDI may lower domestic savings and investment by extracting rents and siphoning off capital through preferential access to local capital markets and local surplus of foreign exchange. Critics fear that instead of closing the gap between saving and investment, they might drive out the local producers out of business and the profits they make might be reinvested in order to extend their market power. Hence, repatriation of the profits might drain capital from the host country. They also argue that instead of fair income distribution and social development, MNCs support some oligarchy of indigenous partners and suppliers. Their use of inappropriate capital intensive technology may produce small labour elite which may render many workers jobless.

For further discussion on the CPEC as threat or opportunity, conceptual framework of Benign and Malign Model will be used to present CPEC as threat or opportunity for Pakistan to come out of the vicious cycle of underdevelopment it is mired in since last seventy two years despite many half-hearted attempts on the part of different democratic and dictatorial regimes.

Table 2. Matrix for the Benign Model and Malign Model

\begin{tabular}{|c|c|c|}
\hline & Benign Model & Malign Model \\
\hline FDI Inflow & $\begin{array}{l}\text { Positive effect on government policy, better institutional } \\
\text { standards, better incentives }\end{array}$ & $\begin{array}{l}\text { Negative effect on government policy, } \\
\text { promoting corruption }\end{array}$ \\
\hline Income & Higher tax income & Tax evasion \\
\hline Equality & Low price of goods and services & Possibility of monopolistic rents \\
\hline Effects & Higher employment and wages & $\begin{array}{l}\text { Crowding out of employment due to capital } \\
\text { intensive techniques }\end{array}$ \\
\hline $\begin{array}{l}\text { Spillover } \\
\text { Effects }\end{array}$ & $\begin{array}{l}\text { Positive spillover } \rightarrow \text { technological advancement, } \\
\text { competition }\end{array}$ & Negative spillover $\rightarrow$ elimination of local firms \\
\hline Trade & $\begin{array}{l}\text { Higher exports } \rightarrow \text { improvement in current account } \rightarrow \text { trade } \\
\text { balance }\end{array}$ & $\begin{array}{l}\text { High import intensity } \rightarrow \text { excessive royalty } \\
\text { payment } \rightarrow \text { worsen current account balance }\end{array}$ \\
\hline $\begin{array}{l}\text { Growth } \\
\text { Effects }\end{array}$ & $\begin{array}{l}\text { Additional supply of capital } \rightarrow \text { lowering the return of } \\
\text { capital } \rightarrow \text { increase in labor wages } \rightarrow \text { fair distribution of } \\
\text { income } \rightarrow \text { better health and education facilities }\end{array}$ & $\begin{array}{l}\text { Adoption of capital intensive techniques } \rightarrow \\
\text { crowding out of local investment } \rightarrow \\
\text { employment level further declines } \rightarrow \text { Poverty }\end{array}$ \\
\hline
\end{tabular}

\section{Opportunities}

According to literature available on the subject, CPEC offers number of opportunities if availed through the adoption of sagacious policies that can lift Pakistan out of economic quagmire it is trapped in. As discussed early in the section of Benign Model every investment brings capital, technology and skills. So is true for CPEC.

Ishrat Hussain, former governor of State Bank of Pakistan and author of many books, in his writings highlights some of the risks and opportunities associated with the CPEC and suggests holistic approach to be adopted given the dynamics of geo-politics and geo-economics of One Belt One Road (OBOR) or Belt Road Initiative (BRI) (Hussain, 2018). According to him, every opportunity comes with some risk. In this regard, he cites an example of 10,000 MW electricity added to the national grid in the span of four years but it has contributed to increase in circular debt. It requires some policy measures such as restructuring or privatisation of the distribution 
companies. If it is not done then the circular debt will keep piling up and creating again the power generation problems (Ibid).

Another risk, he eloquently highlights, is that there is no drinking water and vocational training facilities for the local people living along with the industrial zones in the districts lying in the jurisdiction of CPEC. While showing his fear, he says it may aggravate the already existing anger, alienation and deprivation of local population, resulting in the resistance to CPEC. In order to avoid that situation, he recommends proper planning on the pattern of Sindh EngroThar Coal Mining Project that benefits local population in Thar in employment, contractual services, rural roads, transport services, agricultural development and vocational and on job-training (Ibid).

The study of Wang (2017) enlists the opportunities CPEC offers and according to him those opportunities can lead to sustainable economic development which Pakistan has been aspiring for since long. The investment under CPEC can work as multiplier for Pakistan government and social leaders to improve business environment and increase commercial attractiveness for more investment to trickle in. This would lead to industrialization creating more jobs and changing the socio-economic fabric of the society. The second benefit CPEC could provide is domestic stability and security. He argues that with investment in energy and infrastructure and manufacturing, CPEC will generate more opportunities for the private sector to create jobs and this way the issues related to poverty can be tackled more effectively, especially in Baluchistan where backwardness is haunting the province since the creation of Pakistan.

The third benefit, according to him, CPEC would bring is the regional connectivity by bringing together China, Pakistan, Afghanistan and Iran and Central Asian States which are rich in natural resources. If all these countries are integrated economically, it would be a market of 2 billion people bringing prosperity and stability in the region and at the door steps of people.

Wang (2017) study also highlights the challenges to CPEC and according to him the first and foremost challenge to CPEC is political stability and social governance in Pakistan. In order to integrate people of different regions into the CPEC, there must be fair distribution of resources and efficient allocation of development benefits. How these goals will be achieved, government of Pakistan has to devise structural and institutional mechanism in this regard.

In addition to above opportunities, many studies have highlighted following opportunities and challenges.

\subsection{Special Economic Zones}

The long term plan of CPEC envision the establishment of 27Special Economic Zones in different cities of Pakistan. Khyber Pakhtunkhwa will have eight, Sindh three and Punjab and Baluchistan will have seven each. These SEZs will be targeting sectors like engineering, auto, food packaging and food and pharmaceuticals and food (quote). In Baluchistan the special economic zones are planned to be set-up in Gwadar, Lasbela Industrial Estate, Turbat Industrial Estate, Dera Murad Jamali Industrial Estate, Winder Industrial and Trading Estate, Mini Industrial Estate and Bostan Industrial Estate. The three SEZ in Sindh would include an exclusive Chinese Industrial Estate near Karachi, Textile City near Port Qasim and Marble City Karachi

Once established, Industries in the special economic zones will contribute significantly towards the productive capacity of the industry and will help the country to produce goods and services that Pakistan imports. So they help in import substitutions besides giving major impetus to economic and social development.

\subsection{Enhance Energy Supply}

Before the start of CPEC, Pakistan was facing severe energy crisis that hit hard households and industry. According to studies over 140 million people either have no access to electricity or suffer from as long as 12 hours of load shedding daily when the fact is electricity consumption has grown at an annual rate of 10 percent yearly. Study further say that up to 50,000 have lost jobs due to closure of business as a result of power outages, forcing industry to shift to other countries like Bangladesh. Under CPEC the issue of energy crisis has been addressed and an amount of $\$ 34$ billion has been invested out of total outlay of $\$ 62$ billion. According to plan total of 16,400 megawatts will be produced and 10,400 will be produced by 2018 (ibid) at Quaid-e-Azam Solar Park in Bahawalpur, Jhimper Wind Energy Park, SukiKinari Hydropower project and Kohala Hydropower project.

\subsection{Activity in Real State Sector}

With the launch of CPEC, real state sector, especially in Gwadar has witnessed phenomenal growth of 118 percent and this growth can be attributed to robust demand of seasonal investors and genuine buyers. As a result 
of this trend, prices have been rising by nearly $70 \%$ in Gwadar. In different cities of Pakistan along with Western, Central and Eastern routes, especially in Sindh and Baluchistan, modern housing schemes have been launched in order to accommodate workers, especially, Chinese workers who working on different projects.

\subsection{Export of Fruits}

No doubt CPEC offers rare opportunity to Pakistani producers of fruit to integrate themselves in the regional markets. Some regions of Pakistan like Gilgit-Baltistan are known for its fresh fruits like apricot, apples and cherries. With estimated production of 4,000 tonnes of cherries and up to 20,000 of apples every year, Pakistan can tap into the Chinese market

\subsection{Getting Foothold in Manufacturing}

Yet another opportunity CPEC offers is in the area of manufacturing. As Chinese society is going under tremendous socio-economic and demographic transformation and new middle class is emerging with more power consumption due to rapid prosperity and effective distributary system under the communist party, Pakistani manufacturing industry has got rare opportunity to make inroads into Chinese consumer market. Some studies indicate that China, keeping in view its developmental momentum, will move to high-tech manufacturing like pharmaceuticals, air and space and the technology and will outsource medium to low tech manufacturing like food, textile, paper and leather to cheap labour-centric countries. We think this is rare opportunity for Pakistan manufacturing sector to tap in this opportunity by adding more innovation and quality to its products. This can benefit Pakistan tremendously to earn more foreign exchange to ease off its current account deficit and pay off loans.

Moreover, the challenges thrown by CPEC as it is not easy for economy like Pakistan to tango with economic giant whose power of production has demolished many economies and now challenging the biggest economy of world, that is, USA with $\$ 19$ trillion economy whereas China's economy is still far behind with 14 trillion but it is rising and well integrated into the world economy. The challenges enlisted range from stability to safety to ensure the completion of the projects. Also CPEC faces an external threat especially from India that allegedly does not want Pakistan to progress economically and get stable. So, Pakistan has to be more cautious about external obstructions. The other problem that may haunt the mega project is the lack of consensus amongst all the stakeholders as last time it was witnessed that there was lack of consensus on different routes of CPEC from Gwadar to Kashgar. Security is another threat as the starting and end point are facing uprisings from local populations. For Pakistan, it is necessary to devise mechanism to involve the local population and address the problems like health, education, water, electricity and infrastructure. Without addressing them, there won't be stability. The good thing in this regard is that the government under the command of Pak-army has raised the force of 10,000 strong army unit to protect Chinese staff working on different projects.

However, despite challenges on many fronts, there is school of thought who believes that OBOR is attempt on the part of China to trap countries in the black hole of debt. The next section is going to discuss OBOR as debt trap diplomacy as put by US.

\section{BRI as Debt Trap Diplomacy}

There are host of the people who believe that investment or loans under the garb of OBOR are an attempt on the part of china to rope in the countries into debt trap in the name of infrastructure and energy infrastructure development. Washington based The Centre for Global Development has singled out eight countries which are at the risk of what it calls 'debt stress'. These are Indonesia, Sri Lanka, Kazakhstan, Bangladesh, India, Poland, Laos, and Pakistan. Malaysia under newly elected Prime Minister Dr. Mahatir Mohammad is on the path of disentangling his country from Chinese funded projects and already the project of \$27 million to modernize railway has been cancelled. Dr. Mahatir thinks that Chinese funded projects would harm Malaysian economy than doing any good. More or less same kind of feelings being expressed by the business community in Pakistan and they worry about debt burden (Pakistan Today Monitoring Report, 2018). While cautioning for very careful approach, The chief executive of Pakistan Business Council say "Ten years' tax concessions, 90-year leases for Chinese companies and cheap imports will impact the competitiveness of existing domestic industries"(ibid). Despite reservation being shown by business community over the preferential treatment being offered to Chinese companies, some economist like Mushtaq Khan, former chief economic advisor to the State Bank of Pakistan, acknowledge that the country debt to China is increasing and there is no viable alternative except China, the Beijing cannot afford to bankrupt Pakistan because of its strategic nature and counterweight to India (ibid). According to reports; US, European Union and India have stepped up criticism of projects under OBOR. US has termed these projects as "debt-trap-diplomacy. EU and India say Belt and Road Initiative (BRI) lack transparency and designed to expand the strategic and economic influence in different parts of the world. Some 
people think beyond expansion of strategic influence, they consider BRI is an attempt to colonize countries joining OBOR. American scholar Christine Fair while speaking at a discussion held recently in Washington said "CPEC is an attempt to colonize Pakistan to enrich China. She expressed fears that if the US doesn't bail Pakistan out, China would take control of Gwadar Port because Pakistan is unable to borrow money from the IMF and other donor institutions to pay its immediate loan liabilities (Rajpar, 2018).

Rajpar (2018) argue:

"Successive governments have been unwilling to admit that we are living under a deadly debt cycle. Foreign debt has reached a level where we are unable to pay back our loans through our own resources. The country is heavily dependent on borrowing to pay back loans. The two most recent bailouts from the IMF over the last 10 years have clearly proved this fact. But we keep denying these realities and subjecting ourselves to exercise restrictions: shallow austerity measures for domestic consumption that don't reflect good optics"

Solution, he suggests is that the newly elected Prime Minister Imran Khan should revisit CPEC and renegotiate the terms and condition. He gives an example of Dr. Mahatir who despite debt of $\$ 250$ billion refuses to ink loan deals with China, which carry the risk of $\$ 136$ million as a cancellation penalty to pay. But we do not think it is workable solution keeping in view the strategic nature of Pakistan-China relationship.

Despite issues of transparency, there is wider and intensive debate within the country about the impact of CPEC will have on the local industry when it takes industrial mode by having SEZs. The next section discusses the pre-CPEC impact on the local industry.

\section{The Impact of Uncontrolled Chinese Imports on Local Manufacturers}

With the CPEC yet to be completed, Pakistan manufacturers are feeling the heat of massive influx of Chinese products in the local market which are awash with cheap Chinese good ranging from toys, chocolates, suiting, electronic good, even traditional items like shalwar kameez are coming from China. It has sent jitters among the local manufacturers and they fear closure of the business if not controlled the massive influx. Why Chinese goods are attractive to Pakistani consumers, it is because of the low prices of Chinese products though they are not durable. According to reports, the suiting which had $10 \mathrm{pc}$ share in the market, now stands at $25-30 \mathrm{pc}$ and it is expected that this share will swell to 50-60pc. Giving an example of low prices, Mr. Zubair Motiwalla, a local businessman, said that full suiting of Chinese made is available for Rs 700 and shirts for Rs 300 while Pakistani product of same type cost Rs 1000-1200.

Same challenges are being faced by toys industry and it seems to be on the verge of closure as a result of cheap Chinese toys flooding Pakistani markets. Almost 98pc share is being held by Chinese toys and local stand nowhere. The toys worth Rs 500-600 are arriving in Karachi alone (ibid)

Another area where Chinese products hold sway over the local market is children garments and its share stands at $75 \mathrm{pc}$ following by children shoes $75 \mathrm{pc}$, decorative items $75 \mathrm{pc}$, crockery $90 \mathrm{pc}$ and ladies purses $75 \mathrm{pc}$ (ibid).

Apart from garments, suiting and toys, Chinese products are also making foray into the furniture market and its share stands at $15-20 \mathrm{pc}$.

As a result of Tsunami of Chinese products into Pakistani market, there is wide trade imbalance in favour of china as arrival of goods from China rose to $\$ 9.322$ billion while Pakistani exports remain at dismal figure of $\$ 1.444$ billion (quote-Profit).

According to Pakistan Bureau of Statistics (PBS), "exports from Pakistan stood only \$1.365bn in 2016-17 as against imports of \$7.850bn in 2016-17 from China" (ibid)

Given this situation where local manufacturers are under threat being washed out, resultantly people are losing jobs and their incomes reduced or wiped out, it is incumbent on the state to intervene to protect the local business. If it is not done, it will have devastating consequences.

Whenever, the local industry faces the heat as result of competition from outside industry, the countries resort to 'protectionist' policy to protect home industry. According to experts that protection should not be permanent and should be applied to only to those industry that has potential to grow until it becomes competitive. This view was floated by JS Mill, considered the father of political economy and Austrian economist Fredrick List. The countries which have applied this policy are Britain, USA, Japan, South Korea, and China and so on so forth.

\subsection{Infant-Industry Theory}

In the light of above discussion that focused on the threats and opportunities CPEC offer, the state of Pakistan has to be very much cautious while formulating economic policies dealing with the issues surrounding CPEC 
and SEZs. The government of Pakistan has to assess the impact very judiciously and evaluate the consequences for the local industry which is the backbone of Pakistan economy but still in infant stage, not capable to compete against the developed and mature Chinese industry. With regard to the protection of infant industry, there is intensive debate in the economic literature and this debate has two sides. One side supporting the open competition, irrespective of size and capacity and the other side corroborating the protection of infant industry until it becomes able to compete.

There is no doubt that the industrial sector plays critical role in the economic performance of the country but it is unfortunate that Pakistan's industrial sector has either stagnated or declined. It has largely remained underperforming. And interestingly industry blames government for its failure and government blames industry for being parasite to eat away the resources of the country without enhancing its performance to promote business and economic activity. Its contribution has declined from $25 \%$ in 2000 to $20 \%$. The paper is not going to judge as who is responsible but rather would argue that government has to take steps and devise concrete policy to support industry, especially in SEZs. If it is not done than Pakistan industry would face existential crisis and will create serious economic and social problems, leading to political turmoil.

Given this situation, paper is going to revisit Infant Industry Theory as useful policy guide for long term and sustainable development because authors believes that it is very much relevant to CPEC under which Pakistan's infant industry has to clash with Chinese industry and site of the clash will be SEZs in different regions and the preparedness of Pak-industry seems to be not up to the mark because of historical neglect on the part of both industry and government, weak industrial policies and opportunistic approach of industry. Pak-industry utterly lacks competitive power as it has focused less on technological updates, enhancement of quality of human power and improvement in managerial skills through training skill development programmes. In this situation, state has to step in to protect industry through regulation and subsidies through kicking away the ladder (Chang, 2002), dictates from the developed courtiers to developing countries to open economy to global competition and adopt the "good policies and good institution" approach to reach to the level of economic development in the developed countries.

The roots of Infant Industry Theory lies in the Alexander Hamilton Report on the subject of Manufacturing presented to House of Representative in December 1791 (Rekiso, 2007). In the report, he pleaded for "selective protection of industry, exemption of imported inputs duties, government control and monitoring of quality good produced, facilitation of transport by government and government intervention in encouragement of inventions and promotion of institutions necessary for industrialization". Further, he "saw the role of government complementary to the private sector and significant at early stages of industrialization" (Kicsi \& Buta, 2010) To Hamilton, free trade and investment was destructive to domestic manufacturing from their advanced country rivals (ibid).

\subsection{Infant Industry Theory of List}

Fredrick list was an Austrian Economist. He wrote a book The National System of Political Economy (1841), in which his infant industry argument is very comprehensive and compelling, and as a basic theoretical framework extremely relevant to problems of trade and industrialization of developing countries. In the book, list presented his case for protectionist measures to safeguard the infant industry from outside competition. He argued that infant industry protection is necessary for countries at early stages of industrialization if some countries "outdistanced others" in manufacturing (List, 1841). However, he suggested that that protection need to be temporary in order to facilitate the industry to reach the phase of adulthood and achieve long term industrial development (Rekiso, 2007). List was of the view that backward country cannot rely on the "natural course of things" to promote industrialization, but state has to intervene and hence infant industry promotion and protection is necessary. According to theory, protection is not amid at protecting and promoting inefficient industry but nurturing the one that has potential to gain more competitive power in the long run to produce at low cost as their competitors do. In order to attain the status of economies of scale, list supported 'industrial training or the education of the country as whole and according to Shafaeddin (1998) list referred to human capital development through learning-by-doing and achieving 'dynamic external economics of learning in modern technical jargon (ibid).

According to List, good protection and good incentives are aimed at addressing the risk posed by outside competition and the protection is not only designed to motivating domestic industry but attracting foreign technology, skilled labor and capital (ibid). About the protection, List clarified that it would only be applicable to those industries that have potential to become internationally competitive. In all in all, theory of List suggests that protection and promotion should be selective and temporary and the adult industries should be exposed to 
international competition (ibid).

\subsection{List's Theory of Productive Power}

List was critical of Adam Smith's theory of absolute advantage, in which he argued that trade would be beneficial for all the countries, irrespective of the size and productive capacity. List argued that trade won't be beneficial for all countries if they are at the different levels of industrialization with varying productive capacity. In this regard, List presented a theory of "Productive Power", according to which "the productive power of a nation not only depends on factors of production and possession of natural advantages but also on the availability and stability of institutional factors and their independence and power as nation .....The factors of production must be accompanied by national unity, independence and a common goal and cooperation of productive forces" (Safaedin, 2000)

So, in the light of varying degree of Industrialization amongst different countries, List suggested insulation of local industry from global competition and in the words of Senghass (1989), this "competence gap" requires protection of weaker and infant industry. The main purpose, according to List, of the protection is to enhance the productive power of industry and nation.

In the light of above compelling argument advanced by List, the infant industry theory sees the role of the government as facilitator supplementing industrial effort to gain efficiency, not replacing the market or the private initiatives.

\subsection{Kicking the Ladder Away}

Kicking the ladder away approach has been popularized by Chang (2002) by opposing the policy of free trade and investment supported by developed countries. He argues that the developed countries supported this policy when they attained the status of economies of scale otherwise they had very nationalistic and protectionist approach towards their economy. Chang (2002) cites the economy of South Korea, Japan, Britain and US applying protectionist policy to protect and promote what they called 'infant industry'. General Park adopted this policy in South Korea when its per capita income was hardly $\$ 80$. He applied restriction on the import of foreign good to the extent anyone seen smoking foreign cigarettes was dubbed as traitors (Chang, 2008). China embarked on the same policy of controlling foreign companies investing in China after 1979. Anyone invested in China and prematurely pulled money out of had to pay Tobin Tax. Mahathir Muhammad after winning election in Malaysia has decided to revisit Chinese projects because he thinks that projects are not dubious but an attempt on the part of China to colonize Malaysia. In this regard, he has cancelled two projects and The East Coast Rail Link under review (The News, 2018). This seems to be setback for BRI to expand further and India might be unwilling to join BRI as China seems to be desperate to get Delhi on the Board and join the OBOR.

Authors think same should be done by the government of Pakistan preferring to leverage Pakistani industry against Chinese industry. And there are complained from business houses that they are being discriminated and Chinese industry is given preferential treatment.

Keeping in view the ground realities depicted above, finally the state is waking up and reconsidering to review the CPEC projects and the favourable treatment offered to the Chinese industry. Pakistani minister and advisors say as quoted in Financial Times (2018):

"The country's new government will review BRI investments and renegotiate a trade agreement signed more than a decade ago that it says unfairly benefits Chinese companies".

The ministers and advisors think that previous regime was more tilted towards china and offered undue tax breaks to chines companies that would operate in SEZs in CPEC. Abdul RazakDawood, the Pakistani member of cabinet responsible for commerce, textiles, industry and investment say:

“The previous government did a bad job negotiating with China on CPEC — they didn't do their homework correctly and didn't negotiate correctly so they gave away a lot..... Chinese companies received tax breaks, many breaks and have an undue advantage in Pakistan; this is one of the things we're looking at because it's not fair that Pakistan companies should be disadvantaged," (ibid)

He further say:

"I think we should put everything on hold for a year so we can get our act together," he added. "Perhaps we can stretch CPEC out over another five years or so." (ibid).

The above statement of the Adviser to the Prime Minister on Commerce and Textile has been refuted and statements issued saying that all decisions are taken with consensus. But if we look into the statements of Mr.DawoodRazak, CEO of Descon, an Engineering Pakistani multinational company, has been issuing such 
statement in the past before becoming Advisor to PM on textile and commerce. According to Nasir, (2018):

" Despite benefits CPEC bring in the infrastructure development (investments in power and other infrastructure projects) .............Pakistani firms have been denied contracts for power and other projects; equipment and raw materials for the(se) projects are being imported (from China); labour (technicians, managers, engineers, etc) too are coming from China. (In other words) there is no restriction on (Chinese) firms to involve Pakistani contractors, and use local equipment and labour as they take the lion's share of infrastructure projects,"

He further says:

"We didn't get even a single job because we were expensive. They (Chinese companies) were cheaper because they got certain tax benefits that were not on offer for us (Pakistani bidders)," Mr. Dawood says. "If you know at the start that you are getting certain benefits, you price (your bid) according to the benefits (to undercut your competition). It is not a level playing field... they get a lot more benefits than we do." (ibid)"

More or less same position has been taken by Federation of Pakistan Chamber of Commerce and Industry (FPCCI), Karachi based body of business community. In fact, these positions reflect the deep anxiety of the business community over the preferential treatment being offered to Chinese industries by the government of Pakistan. The policy will have devastating consequences not for the economy but for the country as well if not re-evaluated and reassessed in the light of new emerging realities. Whatever, China has offered Pakistan in the form investment/loans is not charity or gift because countries have their own interests and each country try to realize those interests by formulating prudent policies.

\section{Methodology}

FDI in Pakistan normally throws daunting challenges to the government due to changing international scenario. Since 2000, USA has been the major investing country for FDI in Pakistan. In 2008-09, FDI in Pakistan touched around US $\$ 3.7$ billion and it was the highest in the history of Pakistan. Since last 5 years, Pakistan experienced a new trend of FDI and China has replaced USA and has become the largest source for FDI in Pakistan. Currently, under CPEC most of the foreign investment from China is in power projects. Therefore, CPEC is mainly committed to initiate grand projects and it is believed that FDI benefits would also spillover to SMEs in spite of the fact that SMEs in Pakistan are facing many difficulties. This study is an attempt to observe the awareness of small enterprises as it is believed that CPEC investment will affect the domestic economy of Pakistan with both negative and positive aspects.

\subsection{Research Approach}

A research strategy defines that how a researcher will carry out the investigation including different ways such as surveys, interviews, experimental research, action research case study or systematic literature reviews. Conducting a survey is widely used source for primary data collection and certainly most extensively applied method in quantitative research (Bryman, 2004). In this study, a survey will be conducted to collect the data through a structured questionnaire. This research is qualitative in nature as we will explore and analyze the prevailing opinion of respondents in Karachi with the particular focus on CPEC. The objective of the study is to assess the associated threats and opportunities of CPCE in the context of Pakistan. The study inquires from the owners, manager middle and senior management of various organizations regarding the awareness, challenges, threats and opportunities of CPEC.

\subsection{Data Source}

The study is a mix of primary and secondary data. The primary data has been collected from owners and managers of SMEs operating in Karachi, an industrial hub of Karachi, through online Google web-based forms, whereas the source of secondary data is journal papers, newspaper articles and policy papers.

\subsection{Sampling Method}

The random sampling method is employed in this study. A close ended questionnaire has been filled from 20 respondents of SMEs in Karachi. The data collection for the research has been analyzed through Stata. The study is a combination of comparative and co-relational aspects of the sectors to CPEC. The respondents were required to have at least three years of experience. We identified 13 divergent sectors including construction, off-grid energy, leather, garment, light engineering, fisheries, ICT, hospitality and tourism, dairy and livestock, horticulture and food processing, wholesale and retail trade, and logistic and warehousing. These sectors are selected on the basis of respective GDP contribution and export-orientation.

\subsection{Data Analysis}

Here, we are interested to figure out the viewpoint of the small producers in Karachi. A close ended survey 
questionnaire has been used to address the awareness, challenges and declaration of CPEC as threat or opportunity. The first set of questions covers the awareness of SME's owners regarding CPEC. This aspect allows evaluating the level of awareness of SMEs owners for CPEC projects and programs, related documents, manager's perception and awareness for CPEC and opinions as well. The second set of question highlights the challenges faced by SMEs. This section analyzes challenges regarding hiring of skilled labor, availability of qualified and experience managers, advancement of machinery and technology, purchase of new machinery and land, difficulties in access to finance, provision of legal and business advisory service, government policies and market access. The third section focuses on the perception of respondents about CPEC as an opportunity or threat for all industry and for their own businesses. The basic information of the data is provided by the presentation of graphs and tables using simple descriptive statistics. The last section takes opinion of the respondents regarding need of government policy and support for business.

\section{Results and Discussion}

\subsection{Awareness}

While looking at CPEC, this section analyses the awareness of owner and managers of different industry from Karachi related to opportunities, threats, projects and programs. The likert scale gives enough support in analysing the response of respondents.

Table 3. CPEC Awareness

\begin{tabular}{ccc}
\hline Category & Frequency & Percentage \\
\hline Least aware & 2 & 10 \\
Somewhat aware & 1 & 5 \\
Usually aware & 4 & 20 \\
Much aware & 3 & 15 \\
Fully aware & 10 & 50 \\
\hline
\end{tabular}

\begin{tabular}{|c|c|}
\hline $\begin{array}{l}\text { Fully } \\
\text { aware } \\
50 \%\end{array}$ & $\begin{array}{c}\text { Least aware } \\
\text { Somewhat } \\
\text { aware } \\
5 \% \\
\text { aware } \\
20 \% \\
\text { Much aware } \\
15 \%\end{array}$ \\
\hline
\end{tabular}

Figure 1. CPEC Awareness

This question emphasizes on the complete awareness of CPEC among selected respondents. Most of respondents $(50 \%)$ are fully aware of CPEC whereas, only $10 \%$ respondents are least aware. The result indicates that half of respondents have much knowledge about $\mathrm{CPEC}$ and its impact on industry.

Table 4. Awareness of CPEC Projects and Programs

\begin{tabular}{ccc}
\hline Category & Frequency & Percentage \\
\hline Least aware & 2 & 10 \\
Somewhat aware & 1 & 5 \\
Usually aware & 2 & 10 \\
Much aware & 11 & 55 \\
Fully aware & 4 & 20 \\
\hline
\end{tabular}




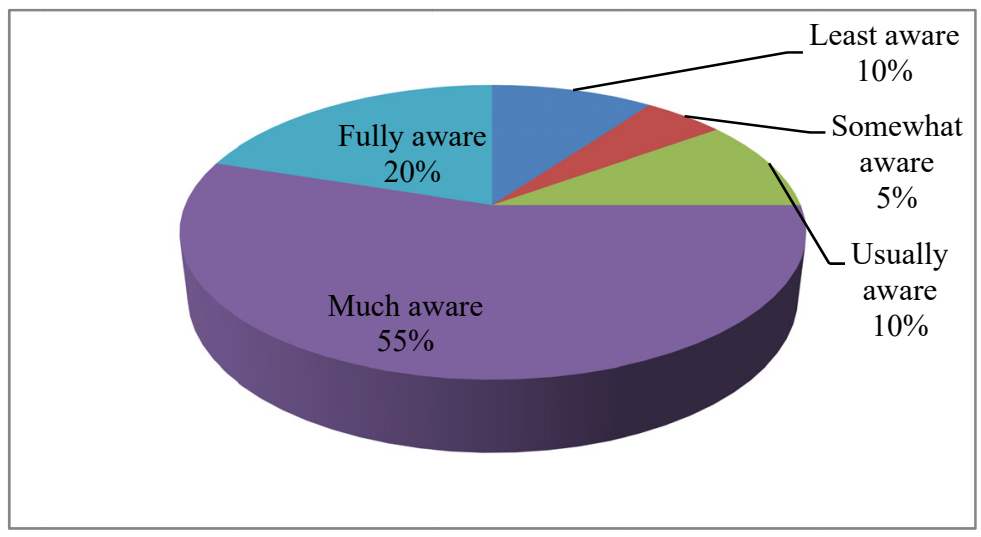

Figure 2. Awareness of CPEC Projects and Projects

This question highlights awareness of CPEC projects and programs selected respondents. 55\% respondents have knowledge regarding projects and programs under CPEC, whereas, only $20 \%$ have fully awareness. The result reveals that majority of the respondent have not fully awareness of CPEC projects and programs that show that may restrict them to gain benefits of these projects. The result indicates a good level of awareness among owner and managers with respect to CPEC projects and programs.

Table 5. Awareness of CPEC as Opportunity for Company

\begin{tabular}{ccc}
\hline Category & Frequency & Percentage \\
\hline Least aware & 1 & 5 \\
Somewhat aware & 0 & 0 \\
Usually aware & 9 & 45 \\
Much aware & 4 & 20 \\
Fully aware & 6 & 30 \\
\hline
\end{tabular}

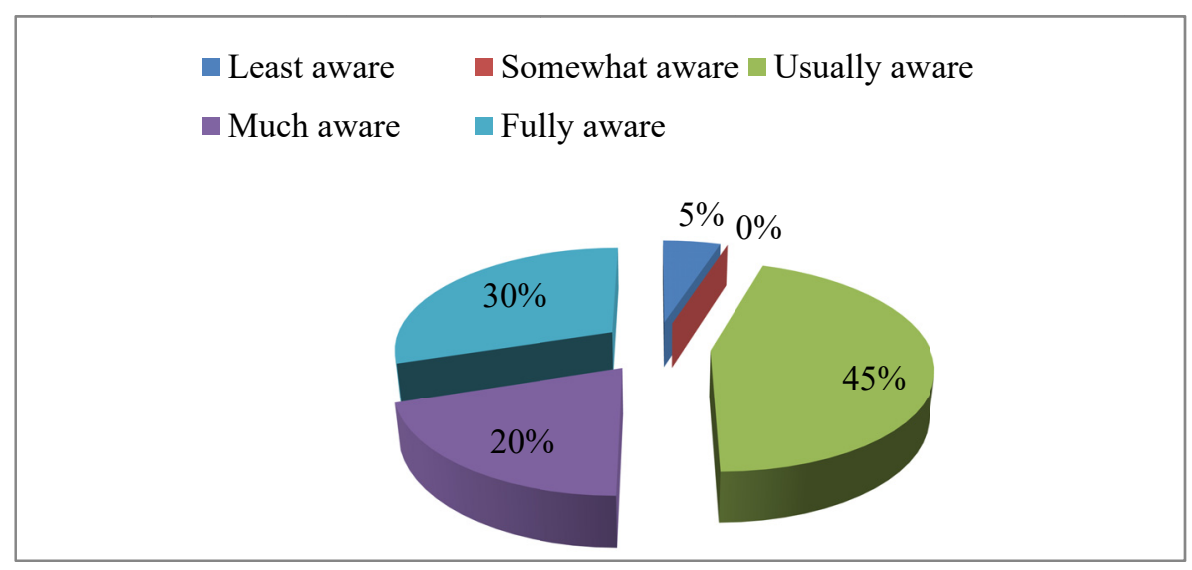

Figure 3. Awareness of CPEC as Opportunity

This question stresses on the awareness of CPEC as an opportunity among selected respondents for their own company. $30 \%$ respondents declared the project of CPEC as an opportunity for their business while $45 \%$ are generally consider CPEC as an opportunity. The result indicates that there is a need to make more focus to highlights the advantages that CPEC has brought not only for local industry but also for company.

Table 6. Manager's Awareness for CPEC Projects and Programs

\begin{tabular}{ccc}
\hline Category & Frequency & Percentage \\
\hline Least aware & 1 & 5 \\
Somewhat aware & 4 & 20 \\
Usually aware & 3 & 15 \\
Much aware & 3 & 15 \\
Fully aware & 9 & 45 \\
\hline
\end{tabular}




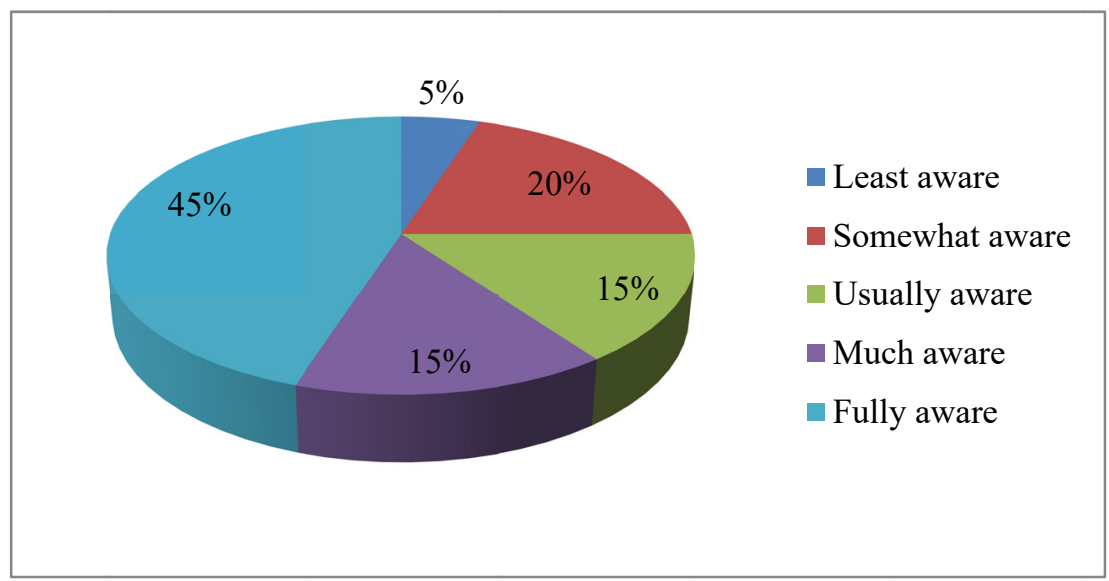

Figure 4. Manager's Awareness for CPEC Projects and Programs

This question shows awareness managers of the organizations regarding projects and programs under CPEC. The result shows that $45 \%$ respondents think that managers in their organization have complete awareness regarding CPEC projects and programs. Only $5 \%$ respondents assume that managers in their organizations have least awareness.

Table 7. Awareness to CPEC related Documents, Articles and Reports

\begin{tabular}{ccc}
\hline Category & Frequency & Percentage \\
\hline Least aware & 1 & 5 \\
Somewhat aware & 8 & 40 \\
Usually aware & 8 & 40 \\
Much aware & 2 & 10 \\
Fully aware & 1 & 5 \\
\hline
\end{tabular}

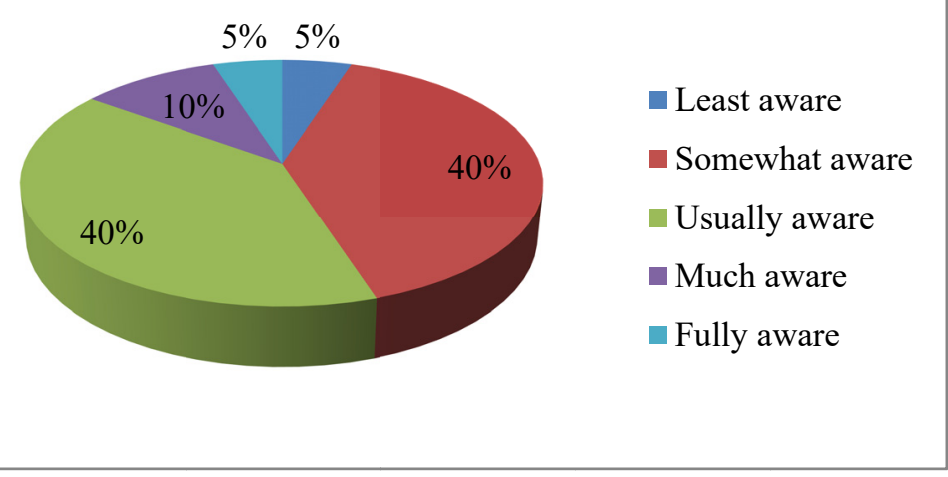

Figure 5. Awareness to CPEC related Documents, articles and Reports

This question focus on the source of awareness regarding CPEC that most of the respondents use for getting knowledge and news related CPEC projects. Only $40 \%$ have fully awareness while reading documents, articles and reports. Whereas, $5 \%$ respondent are least aware regarding CPEC because they have not utilized any given source for getting awareness for CPEC.

Table 8. Manager's Awareness for Threats of CPEC

\begin{tabular}{ccc}
\hline Category & Frequency & Percentage \\
\hline Least aware & 1 & 5 \\
Somewhat aware & 4 & 20 \\
Usually aware & 5 & 25 \\
Much aware & 3 & 15 \\
Fully aware & 7 & 35 \\
\hline
\end{tabular}




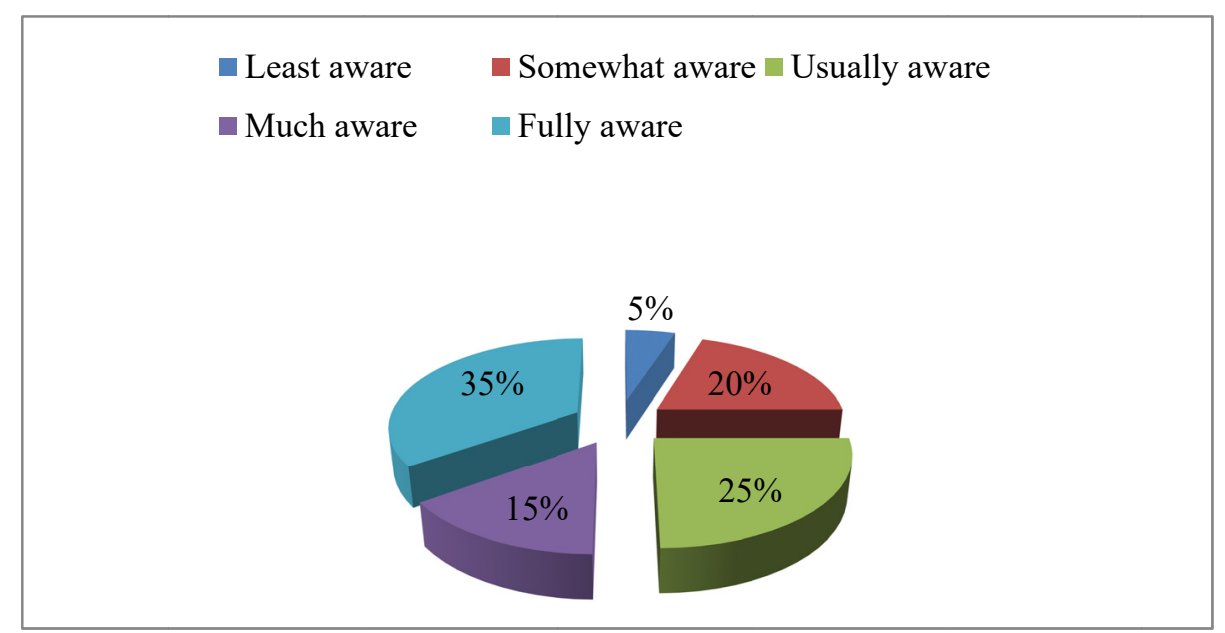

Figure 6. Manager's Awareness for Threat of CPEC

This question focuses on manager's awareness level regarding CPEC as a threat for their organization or industry. Only $35 \%$ respondents agree that CPEC may prove as a big threat for their organization and industry, whereas, $5 \%$ respondents are least aware while considering CPEC as a threat. The result highlights a positive picture of CPEC that will bring more benefits.

\subsection{Challenges Faced by Organizations}

While looking at CPEC, this section analyzes challenges of CPEC that may be faced by local industry due to less competitiveness, technological advancement and skilled labor.

Table 9. Skilled Labor

\begin{tabular}{ccc}
\hline Category & Frequency & Percentage. \\
\hline No challenge & 10 & 50 \\
Above average & 3 & 15 \\
Average challenge & 2 & 10 \\
Big challenge & 4 & 20 \\
Biggest challenge & 1 & 5 \\
\hline
\end{tabular}

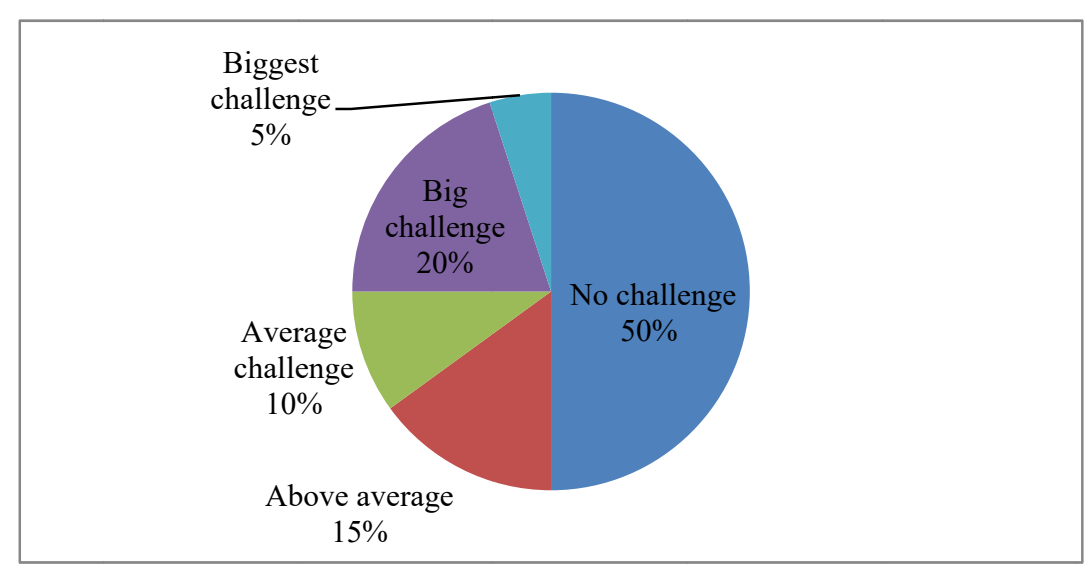

Figure 7. Skilled Labour

Acquiring skilled labor is no challenge by $50 \%$ respondents, $20 \%$ respondents believe that hiring labor will be big challenge, whereas, in the view of $5 \%$ respondents, hiring skilled labor is a biggest challenge. 
Table 10. Qualified \& Experienced Managers

\begin{tabular}{ccc}
\hline Category & Frequency & Percentage. \\
\hline No challenge & 2 & 10 \\
Above average & 5 & 25 \\
Average challenge & 8 & 40 \\
Big challenge & 3 & 15 \\
Biggest challenge & 2 & 10 \\
\hline
\end{tabular}

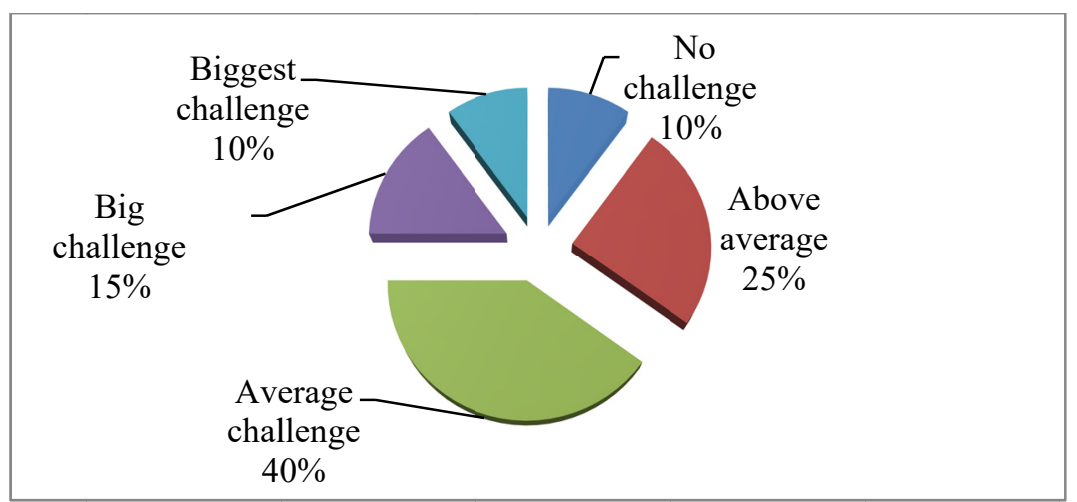

Figure 8. Qualified and Experienced Managers

In the view of $40 \%$ respondent, hiring of qualified and experienced managers is a average challenge, $25 \%$ respondents take it as above challenge whereas, $10 \%$ respondents think that acquiring qualified and experienced managers will be no challenge for local industry and organization.

Table 11. Upgrading of Machinery/Technology

\begin{tabular}{ccc}
\hline Category & Frequency & Percentage. \\
\hline No challenge & 10 & 50 \\
Above average & 1 & 5 \\
Average challenge & 3 & 15 \\
Big challenge & 4 & 20 \\
Biggest challenge & 2 & 10 \\
\hline
\end{tabular}

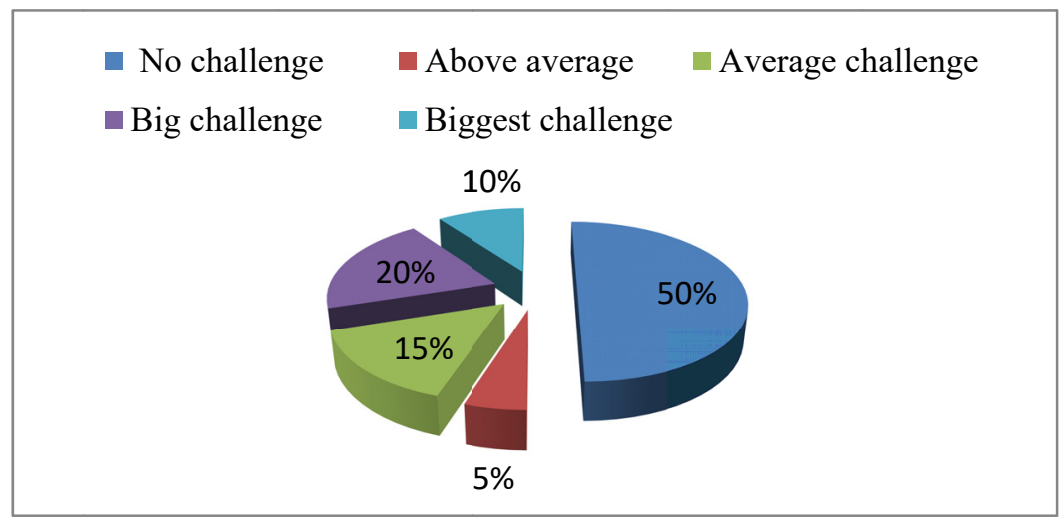

Figure 9. Upgrading of Machinery/ Technology

Half of the respondent (50\%) have not faced any challenges regarding up-gradation of machinery and technology, whereas, $20 \%$ respondent consider it as a big challenges for their company/ organization. Only $10 \%$ respondents think that upgrading of machinery and technology is not a big issue for local industry and organizations. 
Table 12. Purchase of New Machinery

\begin{tabular}{ccc}
\hline Category & Frequency & Percentage. \\
\hline No challenge & 3 & 15 \\
Above average & 6 & 30 \\
Average challenge & 6 & 30 \\
Big challenge & 3 & 15 \\
Biggest challenge & 2 & 10 \\
\hline
\end{tabular}

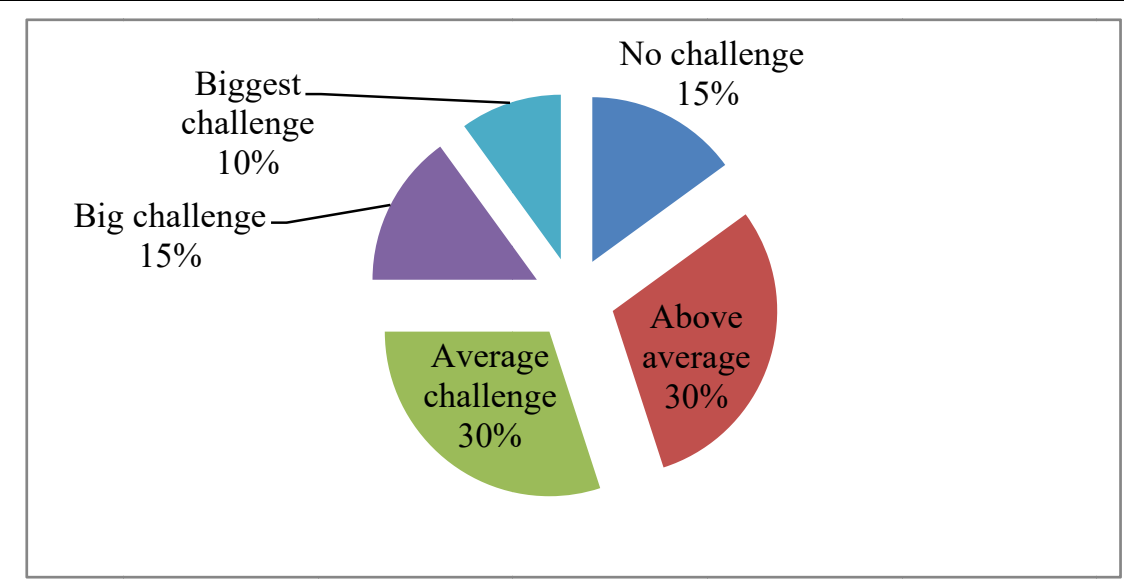

Figure 10. Purchase of New Machinery

In the view of $30 \%$ respondents, they may face above challenge in purchasing of new machinery, whereas more $30 \%$ respondents think that they may face average challenge. Only $15 \%$ respondents consider no challenge and only $10 \%$ respondents take biggest challenge in purchasing new machinery for their company.

Table 13. Purchase of land for construction of office/factory

\begin{tabular}{ccc}
\hline Category & Frequency & Percentage. \\
\hline No challenge & 4 & 20 \\
Above average & 2 & 10 \\
Average challenge & 5 & 25 \\
Big challenge & 6 & 30 \\
Biggest challenge & 3 & 15 \\
\hline
\end{tabular}

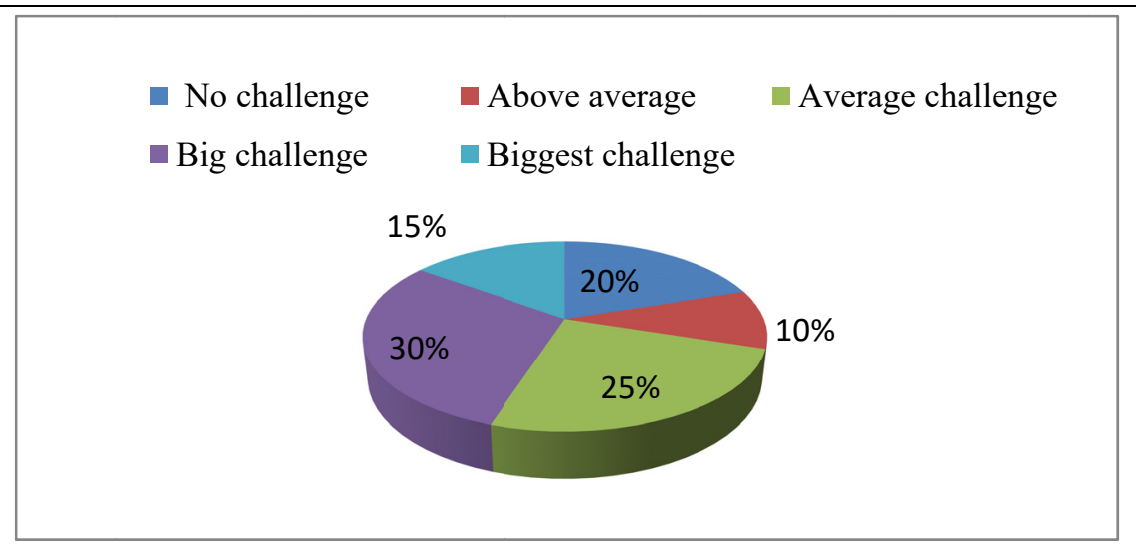

Figure 11. Purchase of Land for Construction of Office/ Factory

We observe that, $30 \%$ respondents face big challenge in purchasing of land for construction of office and factory for local industry, $25 \%$ respondents consider as average challenge, $15 \%$ respondents believe as a biggest challenge. However, $20 \%$ respondents think that purchasing of land will not be challenge for local industry in the presence of CPEC. 
Table 14. Access to finance

\begin{tabular}{ccc}
\hline Category & Frequency & Percentage. \\
\hline No challenge & 0 & 0 \\
Above average & 0 & 0 \\
Average challenge & 4 & 20 \\
Big challenge & 6 & 30 \\
Biggest challenge & 10 & 50 \\
\hline
\end{tabular}

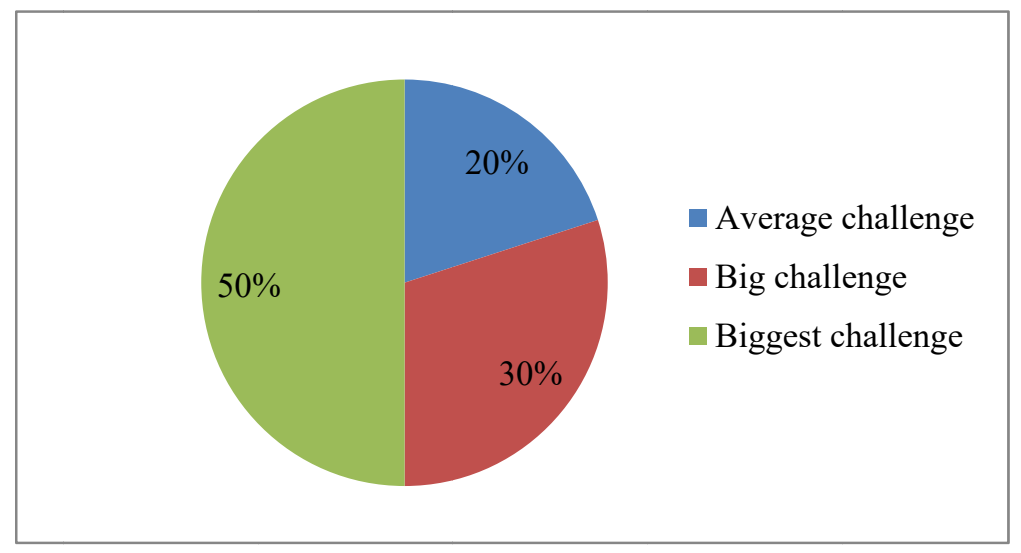

Figure 12. Access to Finance

Access to finance is a major hindrance for local industry in order to expend and upgrade their business. Half of respondents $(50 \%)$ consider that access to finance will be more challenging in the presence of foreign entity in the form of CPEC. $30 \%$ may face big challenge whereas, $20 \%$ may face average challenge in accessing finance facility for their business.

Table 15. Business \& Legal Advisory

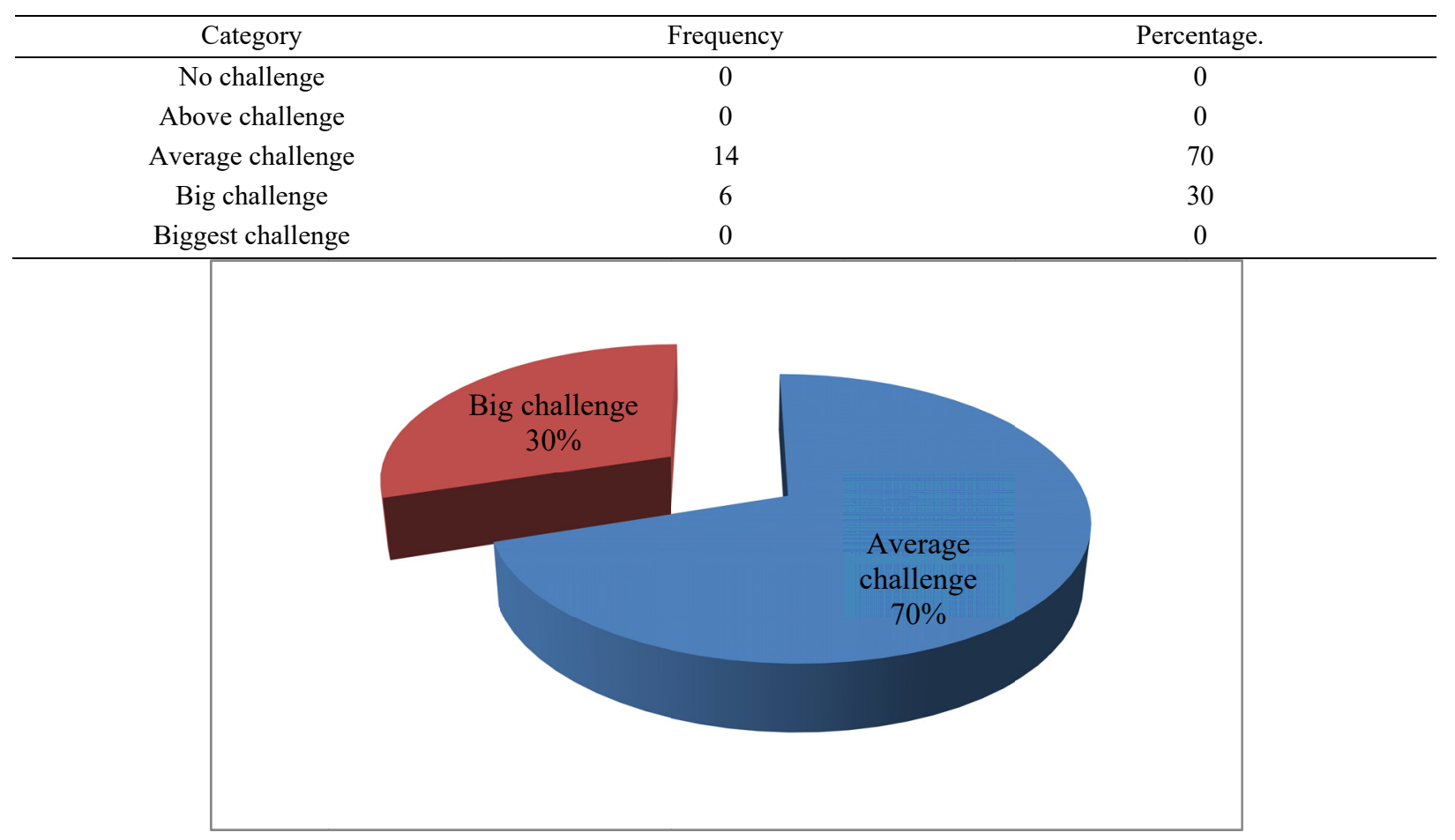

Figure 13. Business and Legal Advisory

Majority of the respondents (70\%) think that business and legal advisory service is an average challenge for their company whereas in the view of $30 \%$ respondents business and legal advisory service is a big challenge. 
Table 16. Policies of government

\begin{tabular}{ccc}
\hline Category & Frequency & Percentage. \\
\hline No challenge & 0 & 0 \\
Above average & 0 & 0 \\
Average challenge & 1 & 5 \\
Big challenge & 17 & 80 \\
Biggest challenge & 2 & 15 \\
\hline
\end{tabular}

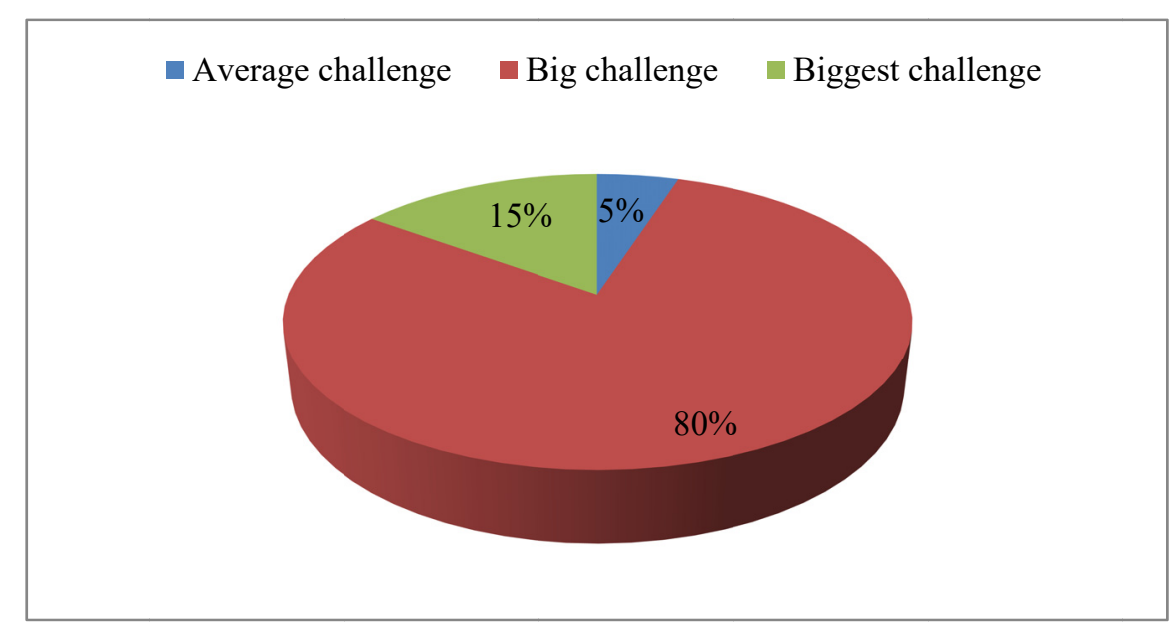

Figure 14. Polices of Government

Most of the respondents ( $80 \%$ ) believe that government policies are the big challenges for the organizations that may create many hurdles to run their business. Whereas, $15 \%$ respondents consider it as a biggest challenge while, $5 \%$ of respondents think that polices of government is an average challenge for their company.

Table 17. Market Access

\begin{tabular}{ccc}
\hline Category & Frequency & Percentage. \\
\hline No challenge & 0 & 0 \\
Above average & 5 & 25 \\
Average challenge & 2 & 10 \\
Big challenge & 2 & 10 \\
\hline Biggest challenge & 11 & 55 \\
\hline \\
\hline
\end{tabular}

Figure 15. Market Access

In the view of $55 \%$ respondents, to market access for their business is a biggest challenge for their company whereas, $25 \%$ respondents consider market access as above average challenge.

While analyzing this sections we observe that market access, government policies and access to finance and business and legal advisory service are the major challenges that most of the companies face in the context of CPEC. 


\subsection{CPEC as Opportunity or Threat}

While looking at CPEC, this section analyses the perception of owner and managers regarding CPEC as opportunity or threats for their business and economy.

Table 18. CPEC as a threat for Industry

\begin{tabular}{ccc}
\hline Category & Frequency & Percentage \\
\hline Strongly disagree & 2 & 10 \\
Disagree & 14 & 70 \\
Neutral & 4 & 20 \\
Agree & 0 & 0 \\
Strongly agree & 0 & 0 \\
\hline
\end{tabular}

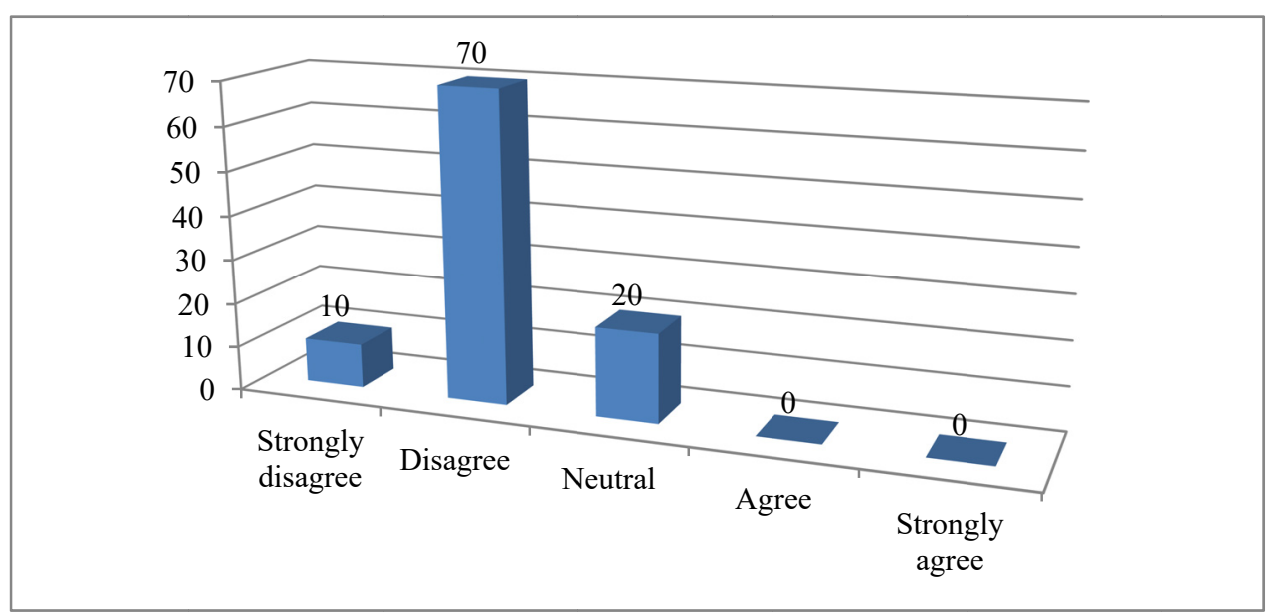

Figure 16. CPEC as a Threat for Industry

The majority of respondents disagree (70\%) and neutral $(20 \%)$ while considering CPEC as a threat for the industry overall. Even, no respondent agree that Chinese firms entering is a threat to the industrial sector.

Table 19. CPEC as a threat for your Business

\begin{tabular}{ccc}
\hline Category & Frequency & Percentage \\
\hline $\begin{array}{c}\text { Strongly disagree } \\
\text { Disagree }\end{array}$ & 8 & 40 \\
Neutral & 8 & 40 \\
Agree & 2 & 10 \\
Strongly agree & 2 & 10 \\
\hline \\
\hline
\end{tabular}

Figure 17. CPEC as a Threat for Your Business (\%) 
The majority of respondents strongly disagree (40\%) and disagree $(40 \%)$ that CPEC will be threat for their business. $10 \%$ are neutral whereas only $10 \%$ agree that CPEC may become a threat for their company.

Table 20. CPEC as an opportunity for the Economy

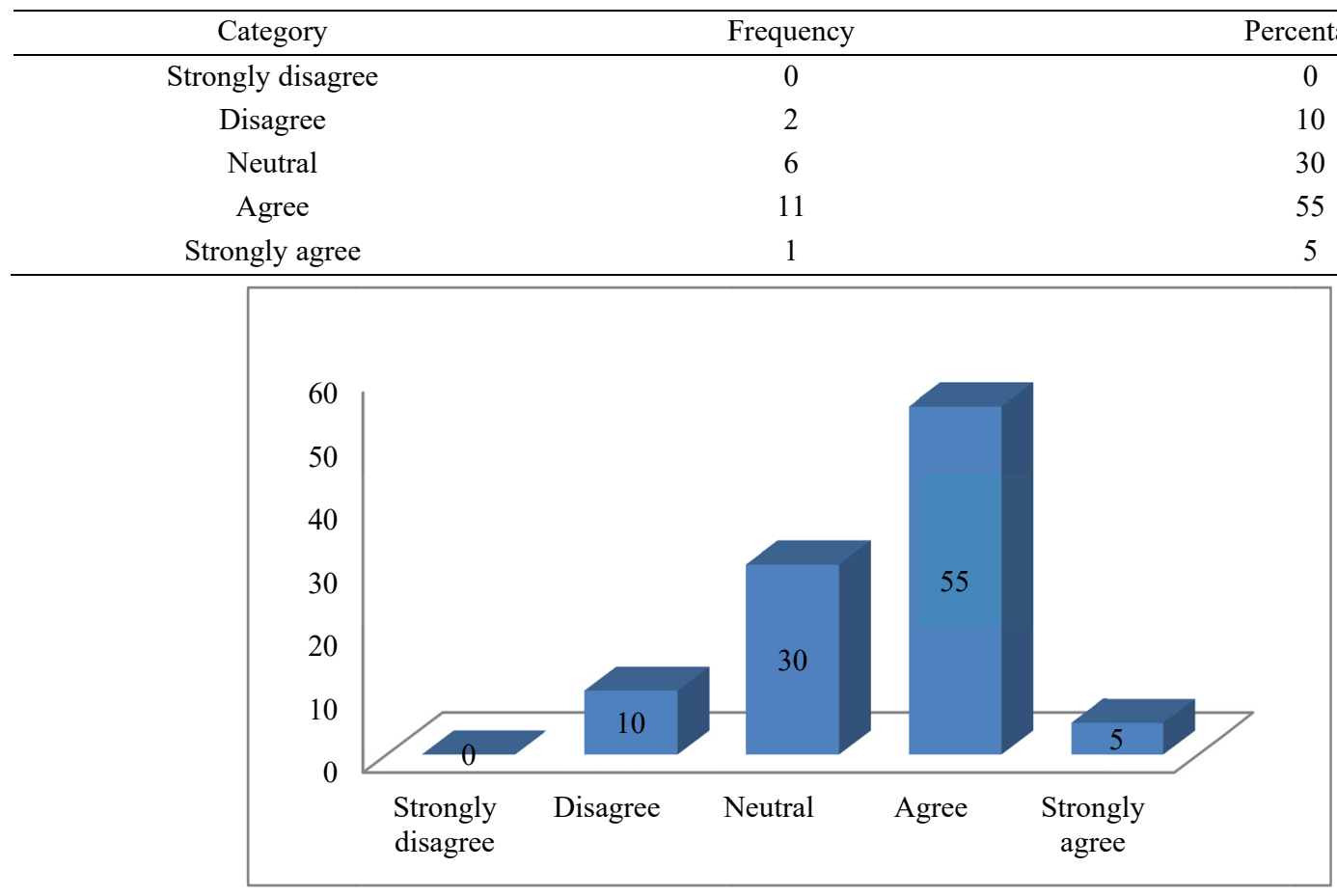

Figure 18. CPEC as an Opportunity for the Economy (\%)

Majority of the respondents agree (55\%), neutral (30\%) and strongly agree (5\%) that CPEC will be prove as an opportunity for the economy. Only $10 \%$ respondents disagree and no respondent strongly disagree that CPEC is an opportunity for the economy.

Table 21. CPEC as an opportunity for my Business

\begin{tabular}{ccc}
\hline Category & Frequency & Percentage \\
\hline Strongly disagree & 0 & 0 \\
Disagree & 4 & 20 \\
Neutral & 5 & 25 \\
Agree & 1 & 5 \\
Strongly agree & 10 & 50 \\
\hline
\end{tabular}

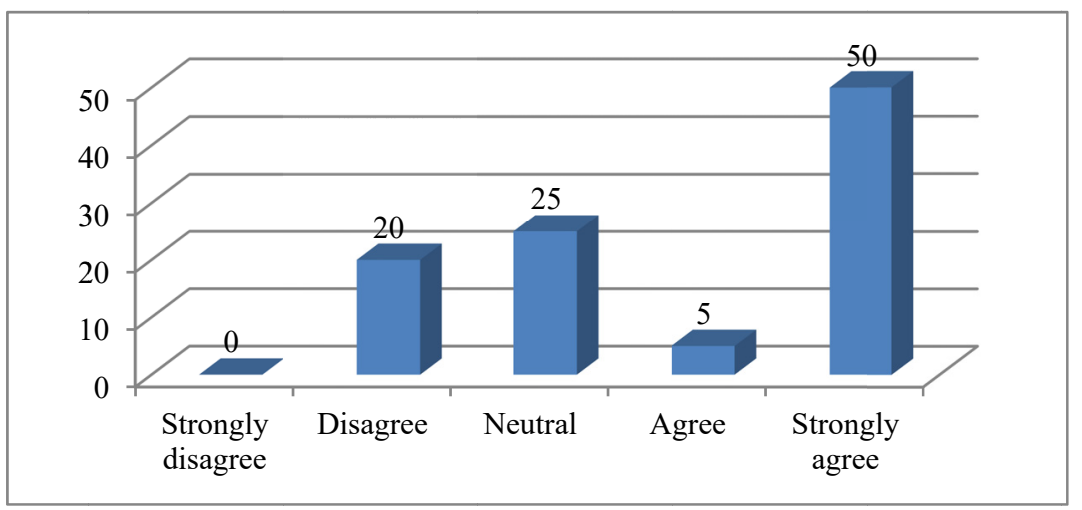

Figure 19. CPEC as an Opportunity for My Business

Majority of the respondents agree (50\%), neutral $(25 \%)$ and agree $(5 \%)$ that CPEC will be prove as an opportunity for their business. However, only $20 \%$ respondents disagree that CPEC will not prove as an opportunity for their business. This section highlights that most of the respondent agree that CPEC will bring 
many opportunity for economy that will boost up their business as well.

\subsection{Consistency in Government Policy and Support}

While looking at CPEC, this section highlights the perception of owners and managers regarding the consistency in government policy and support for business. It is very import to develop polices by federal as well as local government in order to provide basic infrastructures, raw material, financial and legal support for business that facilitates them to expand and grow while availing more opportunities.

Table 22. Consistency in Government Policy and Support

\begin{tabular}{ccc}
\hline Category & Frequency & Percentage \\
\hline Strongly disagree & 7 & 35 \\
Disagree & 7 & 35 \\
Neutral & 4 & 20 \\
Agree & 1 & 5 \\
Strongly agree & 1 & 5 \\
\hline
\end{tabular}

$\square$ Strongly disagree $\square$ Disagree $\square$ Neutral $\square$ Agree $\square$ Strongly agree

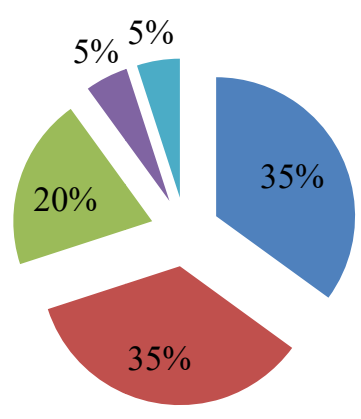

Figure 20. Consistency in Government Policy and Support

Most of the respondents strongly disagree (35\%) and disagree (35\%) that government are providing adequate supports for business whereas, $20 \%$ respondent are neutral. However, only $10 \%$ respondents agree that government policies are sufficient to support their business.

Table 23. Need for consistent Government Policy and Support

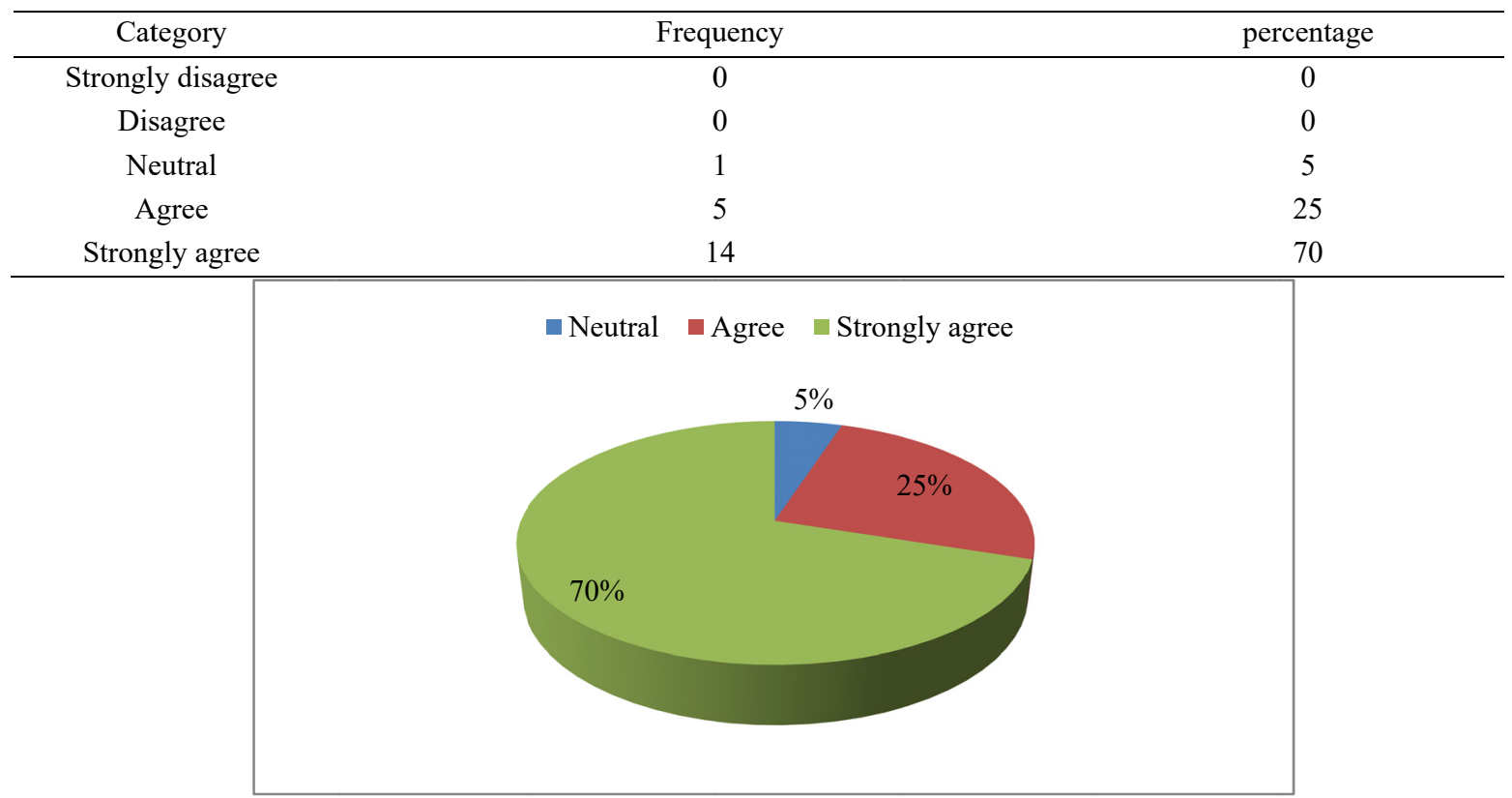

Figure 21. Need for Consistent Government Policy and Support 
Majority of the respondents strongly agree (70\%) that there is need to develop more polices and support system for business sector in order to avail the opportunities even $25 \%$ also agree that government should initiate more policies for providing incentives and enhancement to business whereas only $5 \%$ respondents are neutral regarding need for government policy and support.

\section{Conclusion}

The above discussion on CPEC as threat or opportunity amply shows that CPEC offers great opportunity for Pakistan and Pakistani business to be beneficiary of Chinese largess of massive investment/loans. However, to avert the threats, government has to adopt cautious policy by devising some kind of regulatory mechanism to control the damage to Pakistan industry which is still in infant stage and needs protection against the outside Chinese Industry which is more mature, advanced and has comparative advantage overs Pakistani SMEs as they have more resources such as capital, technology, human resources and technical-know-how. One of the ways of protection is to have joint ventures under which Chinese industry should do partnership with local Pakistani SMEs. This way Pakistan SMEs can grow and enhance their capacity and later on become competitive. China had also adopted same policy when it allowed foreign investment inside China in 1980's. Needless to say, CPEC is great opportunity and hope it will benefit Pakistan economy to lift it from dismal economic state and lead to more industrialization.

\section{References}

Afridi, J., \& Bajoria, J. (2010). China-Pakistan Relations. Council on Foreign Relations, 6, 27-46. Retrieved from https://www.cfr.org/backgrounder/china-pakistan-relations

Anderlini, J., Sender, H., \& Bokhari, F. (2018). Pakistan rethinks its role in Xi's Belt and Road plan. Financial Times, 10. Retrieved from https://www.ft.com/content/d4a3e7f8-b282-11e8-99ca-68cf89602132

Banyan. (2018). The perils of China's "debt-trap diplomacy”. The Economist. Retrieved from https://www.economist.com/asia/2018/09/06/the-perils-of-chinas-debt-trap-diplomacy

Business Dictionary. Infant Industry. $\quad$ Retrieved http://www.businessdictionary.com/definition/infant-industry.html

Chang, H. J. (2002). Kicking away the ladder: Development strategy in historical perspective. Anthem Press.

Chang, H. J. (2010). Bad Samaritans: The myth of free trade and the secret history of capitalism. Bloomsbury Publishing USA. ISBN: 9781596913998.

China's trade with Belt and Road countries reaches \$5t. (2018, September 3). The Nation. Retrieved from https://nation.com.pk/03-Sep-2018/china-s-trade-with-belt-and-road-countries-reaches-5t

Dictionary of Investopia. What is the 'Infant-Industry Theory'. Retrieved from $\mathrm{https} / / /$ www.investopedia.com/terms/i/infantindustry.asp

Dunning, J. (1973). The Determinants of International Production. Oxford Economic Papers, 25(3), new series, 289-336. Retrieved from http://www.jstor.org/stable/2662317

Fazlur, R. (2015). The importance of FDI: Constraints and potential. The Daily Star. Retrieved from https://www.thedailystar.net/supplements/24th-anniversary-the-daily-star-part-2/the-importance-fdi-constrai nts-and-potential

Hussain, I. (2018). CPEC-and-Pakistani-Economy: A way forward. Retrieved from https://cpec-centre.pk/wp-content/uploads/2018/05/CPEC-Pakistans-economy-a-way-forward_Website.pdf

Jamal, N. (2018, January 8). Descon head wants level playing field under CPEC. Daily Dawn. Retrieved from https://www.dawn.com/news/1381431/descon-head-wants-level-playing-field-under-cpec

Kicsi, R., \& Buta, S. (2010). Protectionism and "Infant" Industries. Theoretical Approaches. Economics and Applied Informatics, (1), 173-180. $\quad$ Retrieved from https://EconPapers.repec.org/RePEc:ddj:fseeai:y:2010:i:1:p:173-180

Kuşluvan, S. (1998). A Review of theories of multinational enterprises. Dokuz Eylül Üniversitesi İktisadi İdari Bilimler Fakültesi Dergisi, 13(1), 163-179. https://doi.org/10.1142/9789813238459_0002

List, F. (1885). National System of Political Economy. Longmans, Green and Co, London https://doi.org/10.1002/9781118011690.ch16

Monitoring Report. (2018, July 19). Nikkei Asian Review dubs CPEC as Chinese debt trap,Nikkei Business Review. Pakistan Today. $\quad$ Retrieved from 
https://profit.pakistantoday.com.pk/2018/07/19/nikkei-asian-review-dubs-cpec-as-chinese-debt-trap/

Monitoring Report. (2018, June 4). Post-CPEC Chinese likely to double already awesome 25-30\% market share. Pakistan Today. Retrieved from https://profit.pakistantoday.com.pk/2018/06/04/post-cpec-chinese-likelyto-double-already-awesome-25-30-market-share/

Peterson Institute for Internal Economics think tank. (2018). FDI in Developing Countries and Economies in Transition: Opportunities, Dangers and Challenges. Retrieved from https://piie.com/

Popovici, O. C., \& Călin, A. C. (2014). FDI theories. A location-based approach. Romanian Economic Journal, 17(53). Retrieved from https://EconPapers.repec.org/RePEc:rej:journl:v:17:y:2014:i:53:p:3-24

Rajpur M. (2018). Will the PTI revisit CPEC? The News International. Retrieved from https:/www.thenews.com.pk/print/365333-will-the-pti-revisit-cpec

Rockcliffe-Campbell, A. (2018). China's Belt \& Road initiative is a yet another debt trap! Three years into the project, Pakistan finds self waist deep in debt. Kaieteur News. Retrieved from https:/www.kaieteurnewsonline.com/2018/08/05/chinas-belt-road-initiative-is-a-yet-another-debt-trap-three -years-into-the-project-pakistan-finds-self-waist-deep-in-debt/

Rugman, A. M. (2007). Multinational Enterprises from Emerging Markets. Berlin Roundtable meeting on the Role of the G8 in an Endangered Global Economic and Political Climate, Berlin, June 1-2, 2007.

Salman A. (2015). Pakistan-China Economic Corridor: A cost-benefit analysis. The Express Tribune. Retrieved from https://tribune.com.pk/story/880259/pakistan-china-economic-corridor-a-cost-benefit-analysis/

Samaro, Z. (2009). Tried and Tested: Infant Industry Theory and its Relevance for Africa. https://dx.doi.org/10.2139/ssrn.1489397

Senghaas, D. (1989). Friedrich list and the basic problems of modern development. Economics, 40, $62-76$. Retrieved from https://www.jstor.org/stable/40241192

Shafaeddin, M. (1998). How Did Developed Countries Industrialize? The History of Trade and Industrial Policy: The Cases of Great Britain and the USA. UNCTAD Discussion Papers 139, United Nations Conference on Trade and Development. Retrieved from https://unctad.org/en/Docs/dp_139.en.pdf

Shafaeddin, M. (2000). What did Frederick List Actually Say? Some Clarifications on the Infant Industry Argument. UNCTAD Discussion Paper, No. 149. Retrieved from http://citeseerx.ist.psu.edu/viewdoc/summary?doi=10.1.1.566.7457

Wang, L. (2017). Opportunities and challenges of the China-Pakistan Economic Corridor (CPEC) and implications for US policy and Pakistan. Asia Pacific Bulletien. Retrieved from https://scholarspace.manoa.hawaii.edu/bitstream/10125/48534/apb\%20no.395.pdf

Yu, J. (2018, Jun 11). CPEC is not a Gift. Daily Dawn. Retrieved from https://www.dawn.com/news/1409721

Zahid, J. (2013, November 4). Bearing the brunt: The effect of terrorism on the economy of Pakistan. The Express Tribune. Retrieved from https:/tribune.com.pk/story/626643/bearing-the-brunt-effect-of-terrorism-on-fdi-in-pakistan/

\section{Copyrights}

Copyright for this article is retained by the author(s), with first publication rights granted to the journal.

This is an open-access article distributed under the terms and conditions of the Creative Commons Attribution license (http://creativecommons.org/licenses/by/4.0/). 